\title{
What controls the vertical distribution of aerosol? Relationships between process sensitivity in HadGEM3-UKCA and inter-model variation from AeroCom Phase II
}

\author{
Zak Kipling ${ }^{1}$, Philip Stier ${ }^{1}$, Colin E. Johnson ${ }^{2}$, Graham W. Mann ${ }^{3,4}$, Nicolas Bellouin ${ }^{5}$, Susanne E. Bauer ${ }^{6,7}$, \\ Tommi Bergman ${ }^{8}$, Mian Chin ${ }^{9}$, Thomas Diehl ${ }^{10}$, Steven J. Ghan ${ }^{11}$, Trond Iversen ${ }^{12,13}$, Alf Kirkevåg ${ }^{12}$, \\ Harri Kokkola $^{8}$, Xiaohong Liu ${ }^{14}$, Gan Luo ${ }^{15}$, Twan van Noije ${ }^{16}$, Kirsty J. Pringle ${ }^{4}$, Knut von Salzen ${ }^{17}$, \\ Michael Schulz ${ }^{12}$, Øyvind Seland ${ }^{12}$, Ragnhild B. Skeie ${ }^{18}$, Toshihiko Takemura ${ }^{19}$, Kostas Tsigaridis ${ }^{6,7}$, and \\ Kai Zhang ${ }^{20,11}$ \\ ${ }^{1}$ Department of Physics, University of Oxford, Oxford, UK \\ ${ }^{2}$ Met Office Hadley Centre, Exeter, UK \\ ${ }^{3}$ National Centre for Atmospheric Science, University of Leeds, Leeds, UK \\ ${ }^{4}$ Institute of Climate and Atmospheric Science, School of Earth and Environment, University of Leeds, Leeds, UK \\ ${ }^{5}$ Department of Meteorology, University of Reading, Reading, UK \\ ${ }^{6}$ Center for Climate Systems Research, Columbia University, New York, NY, USA \\ ${ }^{7}$ NASA Goddard Institute for Space Studies, New York, NY, USA \\ ${ }^{8}$ Finnish Meteorological Institute, Atmospheric Research Centre of Eastern Finland, Kuopio, Finland \\ ${ }^{9}$ NASA Goddard Space Flight Center, Greenbelt, MD, USA \\ ${ }^{10}$ European Commission, Joint Research Centre, Institute for Environment and Sustainability, Climate Risk Management \\ Unit, Ispra, Italy \\ ${ }^{11}$ Pacific Northwest National Laboratory, Richland, WA, USA \\ ${ }^{12}$ Norwegian Meteorological Institute, Oslo, Norway \\ ${ }^{13}$ Department of Geosciences, University of Oslo, Oslo, Norway \\ ${ }^{14}$ Department of Atmospheric Science, University of Wyoming, Laramie, WY, USA \\ ${ }^{15}$ Atmospheric Sciences Research Center, the State University of New York, Albany, NY, USA \\ ${ }^{16}$ Royal Netherlands Meteorological Institute, De Bilt, the Netherlands \\ ${ }^{17}$ Canadian Centre for Climate Modelling and Analysis, Environment Canada, Victoria, BC, Canada \\ ${ }^{18}$ Center for International Climate and Environmental Research - Oslo (CICERO), Oslo, Norway \\ ${ }^{19}$ Research Institute for Applied Mechanics, Kyushu University, Fukuoka, Japan \\ ${ }^{20}$ Max Planck Institute for Meteorology, Hamburg, Germany
}

Correspondence to: Zak Kipling (zak.kipling@ physics.ox.ac.uk)

Received: 6 July 2015 - Published in Atmos. Chem. Phys. Discuss.: 25 September 2015

Revised: 8 February 2016 - Accepted: 9 February 2016 - Published: 26 February 2016

\begin{abstract}
The vertical profile of aerosol is important for its radiative effects, but weakly constrained by observations on the global scale, and highly variable among different models. To investigate the controlling factors in one particular model, we investigate the effects of individual processes in HadGEM3-UKCA and compare the resulting diversity of aerosol vertical profiles with the inter-model diversity from the AeroCom Phase II control experiment.
\end{abstract}

In this way we show that (in this model at least) the vertical profile is controlled by a relatively small number of processes, although these vary among aerosol components and particle sizes. We also show that sufficiently coarse variations in these processes can produce a similar diversity to that among different models in terms of the global-mean profile and, to a lesser extent, the zonal-mean vertical position. However, there are features of certain models' profiles that cannot 
be reproduced, suggesting the influence of further structural differences between models.

In HadGEM3-UKCA, convective transport is found to be very important in controlling the vertical profile of all aerosol components by mass. In-cloud scavenging is very important for all except mineral dust. Growth by condensation is important for sulfate and carbonaceous aerosol (along with aqueous oxidation for the former and ageing by soluble material for the latter). The vertical extent of biomass-burning emissions into the free troposphere is also important for the profile of carbonaceous aerosol. Boundary-layer mixing plays a dominant role for sea salt and mineral dust, which are emitted only from the surface. Dry deposition and below-cloud scavenging are important for the profile of mineral dust only.

In this model, the microphysical processes of nucleation, condensation and coagulation dominate the vertical profile of the smallest particles by number (e.g. total $\mathrm{CN}>3 \mathrm{~nm}$ ), while the profiles of larger particles (e.g. $\mathrm{CN}>100 \mathrm{~nm}$ ) are controlled by the same processes as the component mass profiles, plus the size distribution of primary emissions.

We also show that the processes that affect the AODnormalised radiative forcing in the model are predominantly those that affect the vertical mass distribution, in particular convective transport, in-cloud scavenging, aqueous oxidation, ageing and the vertical extent of biomass-burning emissions.

\section{Introduction}

Aerosol particles in the atmosphere play an important role in the climate system on both global and regional scales, through several mechanisms: direct modification of the shortwave and long-wave radiation budgets by scattering and absorption (Ångström, 1962; Schulz et al., 2006; Myhre et al., 2013); effects on clouds and the hydrological cycle, indirectly modifying the radiation budget (Twomey, 1977; Albrecht, 1989; Lohmann and Feichter, 2005); and "semidirectly" by altering the temperature profile of the atmosphere, and evaporating or suppressing cloud, through absorption of radiation (Hansen et al., 1997; Koch and Del Genio, 2010). Consequent changes to circulation patterns may lead to additional effects (e.g. Roeckner et al., 2006). The magnitudes of all these effects are subject to considerable uncertainty.

The relative magnitudes, and even the sign, of these effects are strongly influenced by the vertical distribution of aerosol, and especially its altitude relative to cloud layers. For the direct and semi-direct effects, this is particularly true for absorbing aerosol such as black carbon (Johnson et al., 2004; Zarzycki and Bond, 2010; Samset and Myhre, 2011; Samset et al., 2013). Indirect effects depend on the ambient aerosol where cloud droplets are formed, and are thus most strongly influenced by changes in the aerosol at cloud base.
Some progress has been made in analysing the relative positions of aerosol and cloud layers, and the resulting radiative effects, from satellite observations (Peters et al., 2011; Wilcox, 2012). However, neither passive satellite remote sensing nor ground-based observations can provide wellresolved vertical profiles of aerosol. In situ aircraft observations from large-scale campaigns can provide important constraints (Schwarz et al., 2010, 2013; Kipling et al., 2013; Bauer et al., 2013; Samset et al., 2014; Wang et al., 2014), but nevertheless have limited spatial and temporal coverage. Satellite-based lidar observations such as those from CALIOP show considerable promise in this regard (Koffi et al., 2012; Winker et al., 2013), but the observational constraints on vertical profiles remain rather weak, and there is a large diversity in the profiles simulated by current aerosol models (Textor et al., 2006; Samset et al., 2013).

Aerosol models vary considerably in their complexity, but typically include a range of emission, transport, deposition, microphysical and chemical processes that may affect both the horizontal and vertical distribution of aerosol. In this study, we aim to identify the processes that play a dominant role in controlling the vertical profile using a series of coarse sensitivity tests in one particular model, HadGEM3-UKCA.

We also investigate the extent to which variations in the strength of the processes thus identified can replicate the current inter-model diversity in aerosol vertical profiles, or whether further structural differences between models are required to obtain a similar diversity. The variety of parameterisations used for physical processes will naturally have an impact, but differences in meteorology, resolution and aerosolmeteorology feedbacks may also play a role. We hope that this will aid in identifying some of the model components which might contribute to this diversity, although further sensitivity studies with other models will be required to complement this.

\section{AeroCom}

The AeroCom project (http://aerocom.met.no/) is an international initiative for the intercomparison and evaluation of global aerosol models and a wide range of observations.

Textor et al. (2006) investigated the vertical distribution of aerosol in the AeroCom Phase I models, amongst many other aspects of the aerosol life cycle. They show large variations in the profiles among the models, but these are not attributed to specific processes. Koffi et al. (2012) evaluate the vertical profiles in these models against CALIOP satellite lidar observations, showing that for all models the match to observations varies considerably by both region and season. From the AeroCom Phase II models, Samset et al. (2013) show that the inter-model diversity in the vertical profile of black carbon in particular causes a large diversity in its radiative forcing. 
In this study we use monthly mean aerosol mass mixing ratio fields from the models that contributed to the Phase II present-day "control" experiment (Myhre et al., 2013), referred to as A2.CTRL. The models included here are those contributing to this experiment that provided (a) monthly 3-D mass mixing ratio fields for at least four of sulfate $\left(\mathrm{SO}_{4}\right)$, sea salt (SS), black carbon (BC), organic aerosol (OA) and mineral dust (DU) as well as (b) sufficient vertical-coordinate information to plot vertical profiles and calculate column mass integrals. Some of the models also include ammonium $\left(\mathrm{NH}_{4}\right)$ and nitrate $\left(\mathrm{NO}_{3}\right)$ aerosol components; however, these components are not included in this study.

Based on these requirements, there are 18 suitable models that submitted results to the A2.CTRL experiment, which are summarised in Table 1 along with references giving further detail for each model. Six of these are chemical transport models (CTMs) driven by meteorological fields from a reanalysis data set for the year 2006; the other 12 are general circulation models (GCMs) in which both the meteorology and composition are simulated. Nine of the GCMs submitted results from a nudged configuration (Jeuken et al., 1996; Telford et al., 2008). The three non-nudged (free-running) GCMs submitted a monthly climatology from a 5-year run, while the CTMs and nudged GCMs submitted (at least) monthly output for the year 2006. A number of the models calculate oxidant fields (which control the production of secondary aerosol) online using a tropospheric gas-phase chemistry scheme, while the remainder rely on prescribed oxidant fields from a climatology.

The models use a mixture of modal/sectional and one-/two-moment aerosol schemes. The modal schemes represent the aerosol size distribution as a superposition of a small number of (usually log-normal) "modes", each with its own composition. The sectional schemes divide the size distribution into a (sometimes much) larger number of discrete "bins". In the two-moment schemes, there are separate tracers for number and mass in each mode or bin, allowing the mean particle size to vary within set limits (although the width remains fixed); in the one-moment schemes there is a single tracer for each mode or bin and an assumed size distribution is used. Note that some of the models use distinct schemes for different aerosol components, including HadGEM3-UKCA (described in more detail in Sect. 3) with a six-bin, one-moment sectional scheme for mineral dust and a five-mode, two-moment modal scheme for other aerosol; GISS-modelE, GOCART and HadGEM2 have similar mixed schemes. Three of the models use somewhat different approaches: CAM4-Oslo calculates mass concentrations that are tagged according to production mechanism in clear and cloudy air in four size classes, combined with the use of pre-calculated look-up tables for modal size parameters and aerosol optics which are based on a sectional approach with the respective microphysical processes taken into account (Kirkevåg et al., 2013); CanAM4-PAM uses a piecewise log-normal representation (von Salzen, 2006); and GISS-MATRIX uses the quadrature method of moments (McGraw, 1997).

\section{HadGEM3-UKCA}

HadGEM3 (Hewitt et al., 2011) is the latest version of the Hadley Centre Global Environmental Model developed at the UK Met Office. Although the full model contains many components (atmosphere, land surface, ocean, sea ice etc.), this study is concerned only with the uncoupled atmosphere component, using prescribed sea-surface temperature (SST) and sea ice fields. The dynamical core (Davies, 2005) is nonhydrostatic and fully compressible, with semi-Lagrangian advection and a hybrid-height vertical coordinate. Largescale cloud uses the bulk prognostic scheme of Wilson et al. (2008), with precipitation microphysics based on Wilson and Ballard (1999); sub-grid-scale convection is based on the mass-flux scheme of Gregory and Rowntree (1990) with subsequent modifications.

The standard tropospheric chemistry scheme in UKCA (O'Connor et al., 2014) is used. This includes oxidants $\left(\mathrm{O}_{x}\right.$, $\mathrm{HO}_{x}$ and $\left.\mathrm{NO}_{x}\right)$ and hydrocarbons ( $\mathrm{CO}$, ethane and propane) with 8 emitted species, 102 gas-phase reactions, 27 photolytic reactions and interactive wet and dry deposition. An additional aerosol-precursor chemistry scheme treats the oxidation of sulfur compounds $\left(\mathrm{SO}_{2}\right.$ and dimethyl sulfide, DMS) and monoterpene to form the sulfuric acid and organic compounds that may condense to form secondary aerosol material. There is no differentiation of organic aerosol compounds, or re-evaporation of those which may be volatile.

The aerosol scheme in UKCA (Mann et al., 2016) is the two-moment modal version of the Global Model of Aerosol Processes (GLOMAP-mode; Mann et al., 2010), which follows the M7 framework (Vignati, 2004) in transporting five components (sulfate, sea salt, black carbon, particulate organic matter and mineral dust) in seven internally mixed lognormal modes (four soluble and three insoluble; not all components are found in all modes). Because mineral dust is transported by a separate scheme (Woodward, 2001) in current versions of HadGEM3, only four components and five modes are enabled in the UKCA configuration of GLOMAPmode used here (omitting the two larger insoluble modes that contain only mineral dust). The representation of aerosol microphysical processes in GLOMAP-mode is based on that in its sectional counterpart (GLOMAP-bin; Spracklen et al., 2005 ), with each process acting sequentially in an operatorsplit manner (except nucleation, coagulation and condensation, which are solved iteratively).

New particle formation by nucleation from gas-phase $\mathrm{H}_{2} \mathrm{SO}_{4}$ is calculated following Kulmala et al. (1998). The resulting change in nucleation-mode aerosol is calculated simultaneously with that due to coagulation between particles, as in Vignati (2004), with coagulation kernels calculated following Seinfeld and Pandis (1998). Condensation rates are 


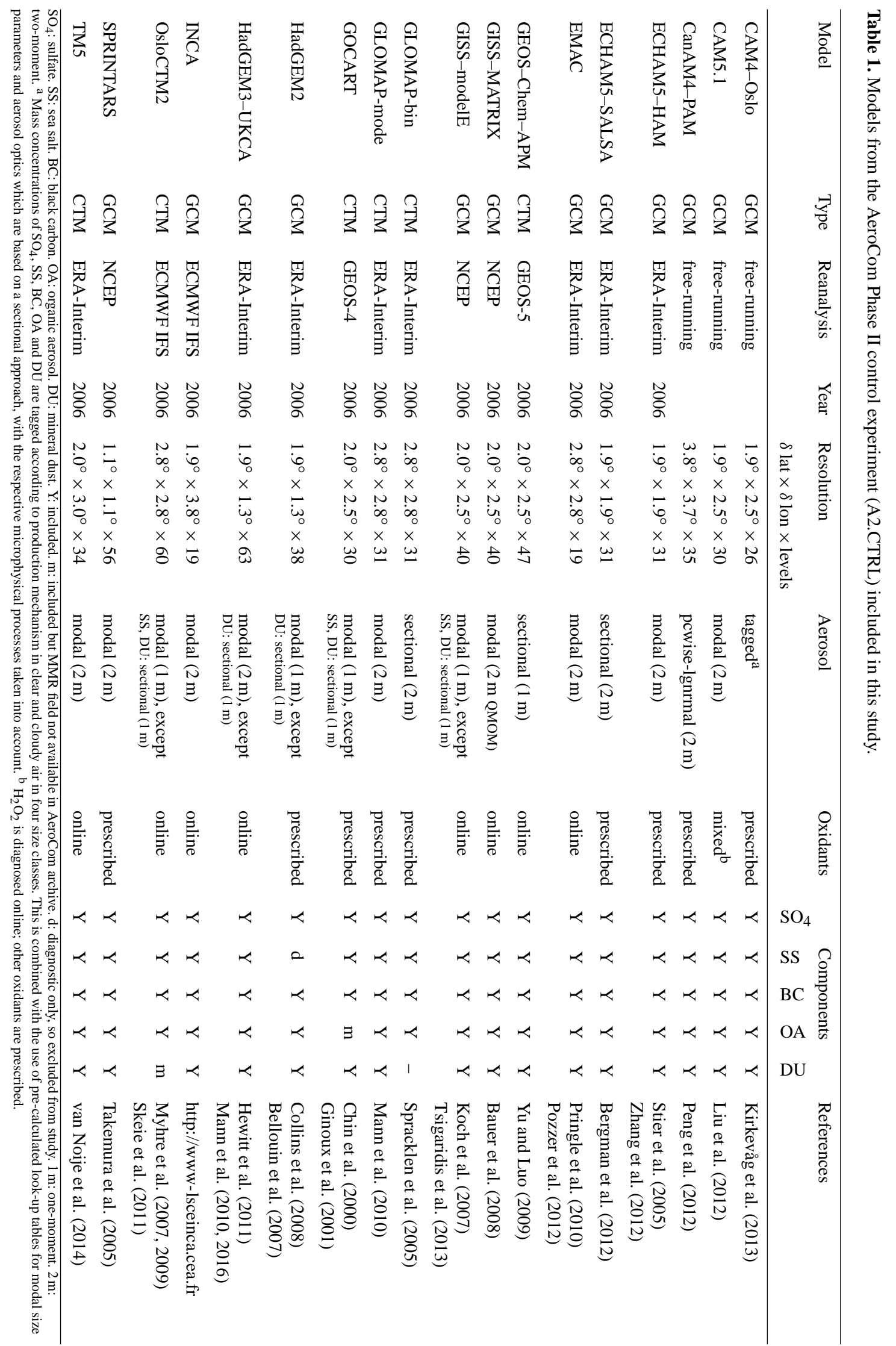


calculated following Fuchs and Sutugin (1971). Soluble material that coagulates with, or condenses onto, insoluble particles "ages" a fraction of these particles, transferring them to the corresponding soluble mode at a rate consistent with a 10-monolayer coating being required for such a particle to become soluble. Soluble particles in clouds larger than a critical size of $37.5 \mathrm{~nm}$ can also grow by aqueous oxidation of dissolved $\mathrm{SO}_{2}$ by $\mathrm{O}_{3}$ and $\mathrm{H}_{2} \mathrm{O}_{2}$, whose concentrations are calculated interactively by the UKCA tropospheric chemistry scheme following Henry's law.

All sizes of soluble and insoluble aerosol particles may be removed by dry deposition and below-cloud impaction scavenging; soluble accumulation- and coarse-mode particles may also be removed by in-cloud nucleation scavenging. Dry deposition and gravitational sedimentation are calculated following Slinn (1982) and Zhang et al. (2001). Below-cloud scavenging follows Slinn (1984), using Beard and Grover (1974) scavenging coefficients and terminal velocities from Easter and Hales (1983), assuming a modified Marshall-Palmer raindrop size distribution (Sekhon and Srivastava, 1971). In-cloud scavenging by large-scale precipitation assumes that $100 \%$ of the aerosol in the soluble accumulation and coarse modes is taken up by cloud water in the cloudy fraction of each 3-D grid box, and is then removed at the same rate at which the large-scale cloud water is converted to rain. (Nucleation, Aitken and insoluble modes are not subject to in-cloud scavenging.) Aerosol is removed immediately, and is not returned to the atmosphere when rain evaporates. Scavenging by convective rainfall uses the inplume approach of Kipling et al. (2013), and acts in a similar manner on the upward water and aerosol fluxes within the convective updraught, rather than on grid-box mean values. In addition, $50 \%$ (by number and mass) of the soluble Aitken mode is susceptible to removal, as a crude representation of the fact that smaller particles can be activated in the faster updraughts found in convective cloud.

The model used here is based on a development version of HadGEM3 using Met Office Unified Model version 7.3, similar to those used in Bellouin et al. (2013) and Kipling et al. (2013) in an atmosphere-only configuration with climatological SST running at N96L38 resolution $\left(1.25^{\circ}\right.$ latitude $\times 1.875^{\circ}$ longitude $\times 38$ vertical levels up to $\sim 40 \mathrm{~km}$ ) with UKCA in a standard tropospheric chemistry and aerosol configuration as described above, with aerosol feedbacks disabled. The large-scale meteorology is nudged (Jeuken et al., 1996) towards the ERA-Interim reanalysis (Dee et al., 2011). In the HadGEM implementation of nudging (Telford et al., 2008, 2013), potential temperature and horizontal wind are relaxed towards the reanalysis fields. The relaxation time constant is $6 \mathrm{~h}$ (the time spacing of the reanalysis data); this choice is validated in Telford et al. (2008). The nudging is applied between levels $14(\sim 4 \mathrm{~km})$ and $32(\sim 21 \mathrm{~km})$ inclusive; levels 13 and 33 are nudged at half strength (i.e. with a $12 \mathrm{~h}$ time constant), and no nudging is performed on levels outside this range.
Sulfur-cycle emissions from a number of sources are included in the model. Ocean DMS emissions are calculated interactively following Jones and Roberts (2004) using prescribed concentrations in sea water from Kettle et al. (1999), while DMS emissions from land are prescribed following Spiro et al. (1992). Volcanic $\mathrm{SO}_{2}$ emissions are prescribed following Andres and Kasgnoc (1998), while anthropogenic $\mathrm{SO}_{2}$ emissions are prescribed following Lamarque et al. (2010). Of the $\mathrm{SO}_{2}$ from all sources, $2.5 \%$ is assumed to be emitted directly as sulfate aerosol (and thus already oxidised to $\mathrm{SO}_{4}^{2-}$ ) rather than into the gas phase. Particulate emissions from anthropogenic sources are split equally by mass between the soluble accumulation and coarse modes, where they are emitted with geometric mean diameters of $150 \mathrm{~nm}$ and $1.5 \mu \mathrm{m}$ respectively; those from volcanic sources are split equally by mass between the soluble Aitken and accumulation modes with geometric mean diameters of 60 and $150 \mathrm{~nm}$ respectively.

Carbonaceous aerosol emissions are taken from the AeroCom hindcast inventory (Diehl et al., 2012), including black and organic carbon emissions from fossil fuel, biofuel and biomass burning through to the end of 2006. Primary particles use the AeroCom recommended size distributions (Dentener et al., 2006), as modified by Stier et al. (2005), but with biofuel emissions using the same distribution as fossil fuel rather than biomass burning. Fossil-fuel and biofuel emissions are added to the lowest model level with a geometric mean diameter of $60 \mathrm{~nm}$, while biomass-burning emissions have a geometric mean diameter of $150 \mathrm{~nm}$ and are distributed uniformly in height over levels 2 to $12(\sim 50 \mathrm{~m}$ to $3 \mathrm{~km}$, compressed over orography). Emissions from all these sources are added to the insoluble Aitken mode. Although our simulations begin in 2008, the fossil fuel and biofuel emissions have little interannual variability and so we simply repeat those for 2006. Biomass burning, however, has significant interannual variability; we use the more recent version 3.1 of the Global Fire Emissions Database (GFED; van der Werf et al., 2010), which does cover the period of our simulations. (Diehl et al., 2012, used version GFED version 2.)

Bin-resolved sea salt and mineral dust emissions are calculated interactively, based on Gong (2003) and Marticorena and Bergametti (1995) respectively. In the case of sea salt, bins with dry diameters smaller than $1 \mu \mathrm{m}$ are emitted into the soluble accumulation mode, while larger bins are emitted into the soluble coarse mode.

Additional gas-phase emissions not included in Diehl et al. (2012) but required by the UKCA chemistry scheme are taken from year 2006 (linearly interpolated) of Representative Concentration Pathway (RCP) 8.5 (Riahi et al., 2011).

All simulations were run with nudged meteorology from September 2008 through to the end of December 2009, allowing 4 months' spin-up before a full year. No re-tuning of the model was performed for the different configurations. To analyse effects on direct radiative forcing, a second matching 
set of simulations were run using the same configurations as the present-day simulations, but with pre-industrial aerosol and precursor emissions based on year 1850 of Lamarque et al. (2010).

It should be noted that, for technical reasons, the model configuration used here differs from that used for the HadGEM3-UKCA A2.CTRL submission, which used a more recent snapshot of the UKCA code, and was run at N96L63 (the same horizontal resolution and model top as used here, but with 63 vertical levels instead of 38) using Lamarque et al. (2010) year-2000 emissions rather than Diehl et al. (2012). Whilst this difference is unfortunate, and we might expect the higher vertical resolution to improve the representation of the vertical profile, we are not aiming to replicate this submission exactly but to compare against the diversity in the ensemble as a whole - and for this purpose, the resolution used here is still well within the range of the other AeroCom models.

\section{Method}

\subsection{HadGEM3-UKCA process sensitivity tests}

The model processes that have the potential to affect the vertical distribution of aerosol broadly divide into four categories: emissions, transport, microphysics/chemistry and deposition. While some model processes can be adjusted via continuous parameters, as in the approach taken by Lee et al. $(2011,2012,2013)$ to assess parametric uncertainty in models, this is not true for all relevant processes. In order to cover the widest possible range of processes, albeit at the cost of a less quantitative assessment of sensitivity and the interactions between processes, we adopt a simple on/off approach for most processes.

Emissions can affect the vertical distribution directly by the vertical range over which they are injected into the model - this is of particular importance for biomass-burning emissions, where plume heights are variable and not particularly well constrained. We consider limiting cases of injecting all such emissions at the surface (BB_SURF), or extending them uniformly in height to the tropopause (BB_TROP/z). The size distribution of emitted particles may also affect the development of the vertical profile, and we consider increasing (EM_LARGE) or decreasing (EM_SMALL) the diameter of all primary particles by a factor of $\sqrt{10}(\approx 3.16$, chosen to match the spacing of HadGEM3 dust bins) while keeping the total mass of emissions constant.

Vertical transport of aerosol in the model is due to largescale vertical advection, boundary-layer turbulent mixing and entrainment into convective plumes. We consider the effect of switching off each of these processes (NO_VADV, NO_BLMIX and NO_CVTRANS respectively).

We also consider the effect of switching off each of the microphysical processes: condensation (NO_COND), coagulation (NO_COAG) and nucleation of new particles (NO_NUCL), as well as the effect of adding boundarylayer nucleation (WITH_BLN) using the cluster-activation approach of Kulmala et al. (2006) - which is available in the model but not included in the standard configuration. We also switch off the in-cloud production of sulfate by aqueous oxidation (NO_WETOX) and the "cloud processing" process that moves activated cloud condensation nuclei (CCN) from the soluble Aitken mode to the accumulation mode (NO_CLDPROC), and consider the limiting cases of instant ageing (AGE_INST) and no ageing (AGE_NEVER) of insoluble aerosol to the soluble modes.

Deposition processes can preferentially remove aerosol from certain ranges in the vertical, and we consider the effect of switching off each process: dry deposition and sedimentation (NO_DDEP), large-scale in-cloud/nucleation scavenging (NO_LS_RO), convective in-cloud/nucleation scavenging (NO_CV_RO) and below-cloud impaction scavenging (NO_WASHOUT). Although the total precipitation in the model is energetically constrained by evaporation at the surface, the division of precipitation between the large-scale and parameterised convective schemes is somewhat arbitrary and varies considerably between different resolutions and configurations of the Met Office Unified Model (which cover global and regional climate modelling and also highresolution weather forecasting); because of this, we also consider the effect of switching off in-cloud/nucleation scavenging (NO_RAINOUT) for both types of cloud at the same time. Finally, we consider the inclusion of a re-evaporation process, in which scavenged aerosol is returned to the atmosphere, where rain evaporates before reaching the surface (WITH_REEVAP) - which is not included in the standard configuration. This follows the approach of Bellouin et al. (2007), with all aerosol scavenged in the layers above released if rain evaporates completely; if only a fraction $\beta$ of the rain evaporates then a fraction $\frac{\beta}{2}$ of the scavenged aerosol is released (i.e. we assume that the loss of rain mass due to evaporation is split evenly between droplets that evaporate completely and those that merely shrink). There is no change in the size distribution between scavenging and reevaporation.

The full set of simulations for the sensitivity tests is summarised in Table 2.

\subsection{Derivation of vertical profiles}

Most of the AeroCom models use a hybrid sigma/pressure vertical coordinate, from which (given the fixed hybrid coefficients for each level and a surface pressure field) a global 3-D pressure field can easily be calculated, while neither geometric nor geopotential height is readily available. The exceptions are the HadGEM models, which use a hybrid-height vertical coordinate, but for these a prognostic pressure field is readily available in the output. For simplicity across the 
Table 2. Configurations of HadGEM3-UKCA used for process sensitivity-test simulations.

\begin{tabular}{|c|c|c|}
\hline & Configuration & Description \\
\hline \multirow{2}{*}{ 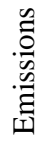 } & BB_TROP/z & Biomass-burning emissions injected uniformly in height up to tropopause \\
\hline & EM_LARGE & All primary particle sizes increased by a factor of $\sqrt{10}$ (total mass unchanged) \\
\hline \multirow{3}{*}{ 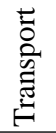 } & NO_VADV & No large-scale vertical advection of aerosol \\
\hline & NO_BLMIX & No boundary-layer mixing of aerosol \\
\hline & NO_CVTRANS & No entrainment into convective plumes (and thus also no convective in-cloud/nucleation scavenging) of aerosol \\
\hline \multirow{4}{*}{ 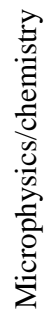 } & NO_COND & No condensation from gas phase onto existing aerosol \\
\hline & NO_COAG & No coagulation of aerosol particles \\
\hline & AGE_NEVER & Insoluble particles never age to soluble modes (i.e. $\infty$ monolayers required) \\
\hline & NO_CLDPROC & No Aitken $\rightarrow$ accumulation mode transition due to aerosol activation \\
\hline \multirow{6}{*}{ 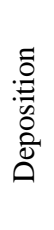 } & NO_DDEP & No dry deposition or sedimentation of aerosol \\
\hline & NO_LS_RO & No large-scale in-cloud/nucleation scavenging (rainout) of aerosol \\
\hline & NO_CV_RO & No convective in-cloud/nucleation scavenging (rainout) of aerosol \\
\hline & NO_RAINOUT & No in-cloud/nucleation scavenging (rainout) of aerosol \\
\hline & NO_WASHOUT & No below-cloud impaction scavenging (washout) of aerosol \\
\hline & WITH_REEVAP & Re-evaporation (release of scavenged aerosol due to evaporation of precipitation) switched on \\
\hline
\end{tabular}

full range of models, we thus choose to work with vertical profiles in pressure coordinates.

For all the models used here, monthly mass mixing ratio fields are available for each of the included aerosol components (either directly or by summing over several tracers for different size bins or modes). These are based on the mass of the dry aerosol component, not including any water taken up by hygroscopic aerosol. For a global (or regional) mean vertical profile, the mean mixing ratio is taken (on model-level surfaces) and plotted against monthly mean pressure (again averaged on model-level surfaces).

For the HadGEM3-UKCA sensitivity tests, we also calculate size-resolved vertical number profiles in the form of condensation nuclei $(\mathrm{CN})$ with dry diameters greater than 3 , 30,100 , and $500 \mathrm{~nm}$. These are calculated by integrating the relevant portion of the log-normal size distribution for each of the UKCA aerosol modes, and adding the number of mineral dust particles based on the separate one-moment sectional dust scheme. Where the $\mathrm{CN}$ size cut-off falls within a dust bin $D$, we calculate this assuming that the number distribution within the bin is log-uniform. (This is not entirely consistent with the dust scheme itself, which assumes that the volume distribution - rather than the number distribution - is log-uniform within each bin. Any error introduced, however, will only affect $\mathrm{CN}>100 \mathrm{~nm}$ and $\mathrm{CN}>500 \mathrm{~nm}$ since the smallest dust bin starts at $63.5 \mathrm{~nm}$.)

\subsection{A vertical position metric}

As a means of quantifying the vertical position of aerosol, such that it can be plotted on a map or as a zonal mean on a line graph, we calculate the vertical centre of mass of each aerosol component, $C$, in each column in pressure coordinates (i.e. the aerosol-mass-weighted mean pressure level):

$\bar{p}_{C}=\left(\sum_{k} m_{k}^{(C)} M_{k} p_{k}\right) /\left(\sum_{k} m_{k}^{(C)} M_{k}\right)$,

where $p_{k}$ is the mid-point pressure of model layer $k, m_{k}^{(C)}$ is the mass mixing ratio of aerosol component $C$ in that layer, and $M_{k}$ is the contribution of layer $k$ to the column air mass. Where $M_{k}$ is not provided in the model output, it is calculated assuming hydrostatic balance as

$M_{k}=\frac{1}{g}\left|p_{k+1 / 2}-p_{k-1 / 2}\right|$,

where $p_{k \pm 1 / 2}$ are the pressures at the upper and lower boundaries of layer $k$, and $g$ is the acceleration due to gravity (assumed constant, neglecting a small decrease with height over the troposphere). This construction is similar to the "extinction mean height diagnostic" of Koffi et al. (2012), and this metric could be analogously termed the "mass mean pressure level diagnostic". 
We can proceed similarly with the $\mathrm{CN}$ number profiles in HadGEM3-UKCA, calculating the vertical centre of number of $\mathrm{CN}$ with diameter larger than $a$ in each column (i.e. the $\mathrm{CN}$-number-weighted mean pressure level):

$\bar{p}_{\mathrm{CN}>a}=\left(\sum_{k} n_{k}^{(>a)} M_{k} p_{k}\right) /\left(\sum_{k} n_{k}^{(>a)} M_{k}\right)$,

where $n_{k}^{(>a)}$ is the number of $\mathrm{CN}$ larger than $a$ per unit mass of air in layer $k$.

\subsection{Impact on radiative forcing}

To investigate the impact of the various processes considered in HadGEM3-UKCA on the direct aerosol effect, due to the change in vertical profile, we calculate the instantaneous direct radiative effect (DRE) at the tropopause due to aerosol for each of the configurations in Table 2 using both presentday and pre-industrial emissions. This is done using a double call of the radiation scheme in the model, as in Bellouin et al. (2013), with aerosol effects active only in a diagnostic call; the difference in net radiative fluxes between the two calls gives the instantaneous DRE due to all aerosol:

$\mathrm{DRE}=F_{\text {with aerosol }}^{\downarrow \text { net }}-F_{\text {without aerosol }}^{\downarrow \text { net }}$.

Note that these only differ in the extinction due to scattering and absorption by the aerosol, and not due to aerosol-induced changes in cloud albedo, as the cloud droplet number is not coupled to the aerosol scheme in either simulation.

By further taking the difference between the present-day and pre-industrial DRE, we obtain the direct radiative forcing (DRF) due to present-day anthropogenic aerosol:

$\mathrm{DRF}=\mathrm{DRE}_{\mathrm{PD}}-\mathrm{DRE}_{\mathrm{PI}}$.

The interaction between UKCA aerosol and the radiation scheme in HadGEM3 is described in detail in Bellouin (2010).

Much of the change in forcing between different configurations, however, is likely to be due to changes in the total amount of aerosol in the atmosphere rather than its vertical distribution. In order to (at least partially) remove such effects, we consider global-mean radiative forcing normalised by global-mean anthropogenic aerosol optical depth (at $550 \mathrm{~nm}$ wavelength):

$\mathrm{NRFA}=\frac{\left\langle\mathrm{DRE}_{\mathrm{PD}}-\mathrm{DRE}_{\mathrm{PI}}\right\rangle}{\left\langle\mathrm{AOD}_{\mathrm{PD}}-\mathrm{AOD}_{\mathrm{PI}}\right\rangle}$,

where the angle brackets denote a global mean. This is similar to the definition of "aerosol radiative forcing efficiency" in, for example, García et al. (2012), but calculated from global rather than regional DRE and aerosol optical depth (AOD). An alternative approach would be to define NRFA locally and then take the global mean; however, this results in a very noisy metric that is difficult to interpret.

\section{Results}

\subsection{Global-mean vertical mass profiles}

The annual- and global-mean vertical profiles of each aerosol component are shown in Fig. 1, from the AeroCom A2.CTRL models (upper panel) and our HadGEM3-UKCA process-sensitivity tests (lower panel). In order to highlight the variations in vertical profile, rather than those in total amount, these are shown as normalised mixing ratios, such that the value at the surface is always unity. The multi-model mean and standard deviation from AeroCom models are also indicated (these are the geometric mean and standard deviation, in order to appear symmetric on the logarithmic scale). The actual mixing ratio values at the surface and at selected pressure levels from the AeroCom models are given in Tables S1-S5 in the Supplement, and the column burdens from both data sets are shown in Fig. 2. Although this study is primarily concerned with the vertical distribution rather than total burden, it is worth noting that the burdens of all components vary by about a factor of four among the AeroCom models, and by an order of magnitude among the sensitivity tests.

In the AeroCom models, the inter-model variations in vertical profile are greatest for black carbon and organic aerosol, where the decrease in mass mixing ratio between lower and upper troposphere ranges from very little (CAM4-Oslo) to 2 orders of magnitude (GISS-MATRIX). The variations for sulfate are smaller, ranging from slightly increasing with height (HadGEM3-UKCA) to a decrease of just over 1 order of magnitude (HadGEM2). For sea salt and mineral dust, all the models produce a significant decrease with height, ranging between 2 and 5 orders of magnitude for sea salt and 1 and 3 for mineral dust.

The spread of the profiles from the sensitivity tests generally covers the inter-model spread in the AeroCom models, suggesting that sufficiently strong variations in the processes we have considered can largely replicate the model diversity as far as global-mean profiles are concerned.

The main feature that is not replicated is the "inverted S" shape exhibited by several of the AeroCom models for sulfate, black carbon and organic aerosol: specifically the ECHAM5-HAM, INCA and SPRINTARS models exhibit this shape for all three components; ECHAM-SALSA and GOCART do for sulfate, while GISS-modelE does for black carbon and organic aerosol. This is seen very weakly in some of our simulations for sulfate, and for black carbon and organic aerosol only in BB_TROP/z; however, no configuration of HadGEM3-UKCA shows such a strong shape as can be seen in, for example, ECHAM5-HAM.

Also, while in many of the AeroCom models the sulfate mass mixing ratio decreases by an order of magnitude between the surface and middle/upper troposphere, almost all of the sensitivity tests show a more vertically uniform profile, apart from NO_CVTRANS and NO_LS_RO. This is in 

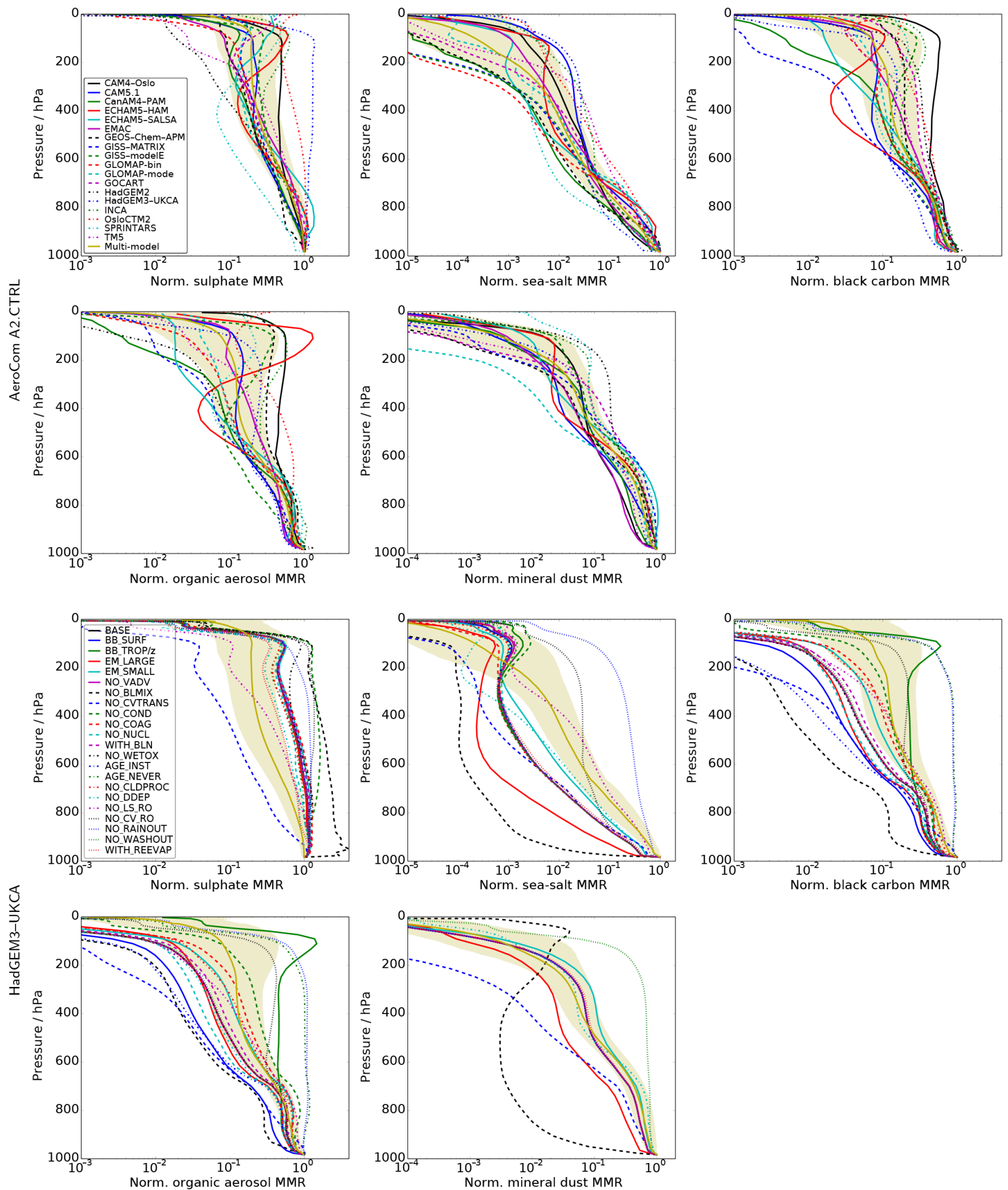

Figure 1. Annual- and global-mean vertical profiles of sulfate, sea salt, black carbon, organic aerosol and mineral dust mass mixing ratio from the AeroCom Phase II models (top) and HadGEM3-UKCA sensitivity-test simulations (bottom), normalised to the value at the surface. The multi-model geometric mean and standard deviation of the former are indicated by the yellow line and shading. 

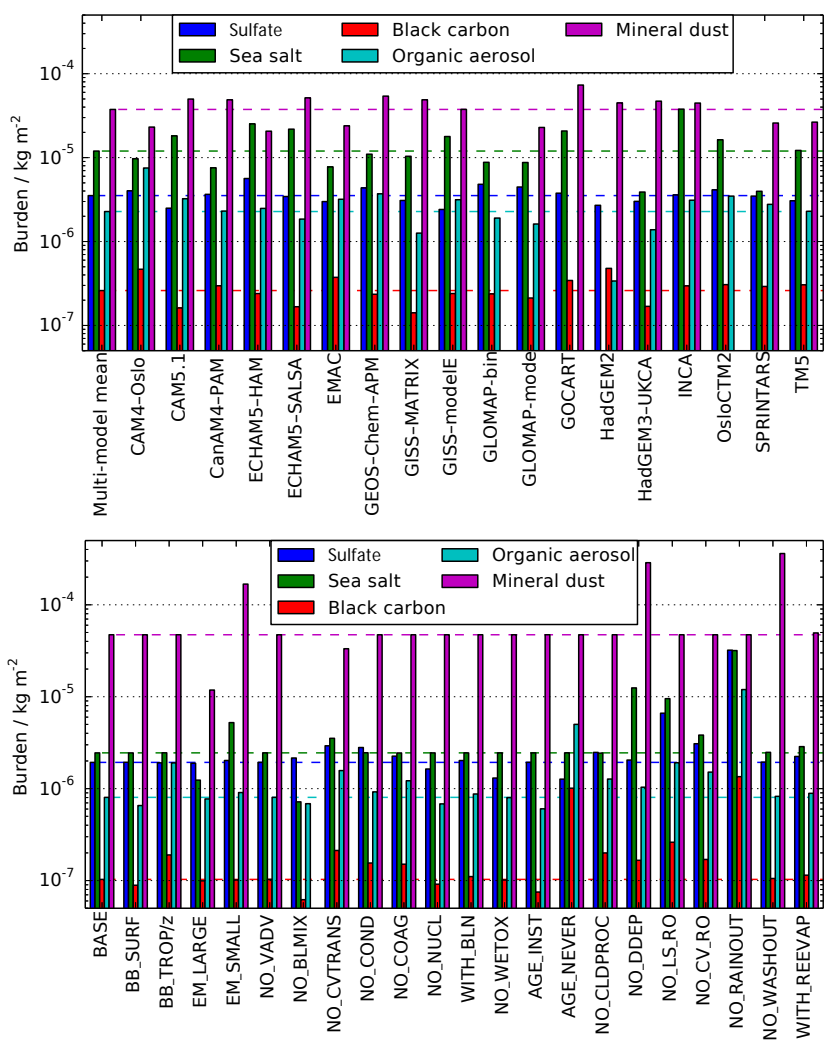

Figure 2. Annual- and global-mean column burdens of sulfate, sea salt, black carbon, organic aerosol and mineral dust from the AeroCom Phase II models (top) and HadGEM3-UKCA sensitivity-test simulations (bottom). The dashed lines represent the multi-model geometric mean (top panel) and the values from the BASE simulation (bottom panel) to aid comparison.

contrast to black carbon and organic aerosol, where the sensitivity tests produce a wide range of vertical profiles similar to those seen in AeroCom, with a larger subset of processes showing significant effects.

\subsection{Zonal-mean vertical position by mass}

The zonal-mean vertical positions of each aerosol component (as represented by the mass-weighted mean pressure level) are shown in Fig. 3, for the AeroCom A2.CTRL models (upper panel) and our HadGEM3-UKCA process-sensitivity tests (lower panel). The multi-model mean and standard deviation from AeroCom models is also indicated. The AeroCom models show a large inter-model spread for all components, and for sulfate, black carbon and organic aerosol the profiles vary between fairly flat (vertical position independent of latitude) and strongly "U-shaped" (aerosol located much higher in polar regions than tropics). Specifically, the CAM4-Oslo, EMAC, GEOS-Chem-APM and HadGEM3UKCA models show a fairly flat profile for all three components; in addition CanAM4-PAM and GISS-modelE do for sulfate, while GISS-MATRIX does for organic aerosol, and GOCART, HadGEM2 and TM5 do for both black carbon and organic aerosol. The remaining cases show a distinct "U" shape.

Unlike the other components, sea salt is strongly asymmetric between the hemispheres (probably due to the difference in land fraction, and strong emissions driven by Southern Ocean winds). Mineral dust shows a "W" shape in several of the models (strongly in CAM4-Oslo, CAM5.1, GISSmodelE and TM5; weakly in EMAC, GEOS-Chem-APM and GISS-MATRIX), with an additional peak in the tropics (probably due to dust transported aloft from desert regions e.g. in the Saharan outflow). In the remaining models, mineral dust shows a "U" shape as seen for other components.

The HadGEM3-UKCA simulations are all on the flat end of the spectrum seen in the AeroCom models, and generally cover a smaller vertical range. None of the configurations in our process-sensitivity test are able to reproduce the " $U$ shaped" curves seen in many of the AeroCom models, except for mineral dust and for sulfate in the NO_WETOX simulation. The Southern Hemisphere part of this shape is seen for carbonaceous aerosol in many of our simulations, but there is no corresponding rise in the Northern Hemisphere. For all components, many of the simulations produce curves similar to BASE, with only a minority of processes significantly shifting the vertical position of the aerosol. The set of processes that have the strongest effects varies among the different aerosol components.

For sulfate, convective transport and large-scale rainout (in-cloud nucleation scavenging, the dominant removal process) have the largest effects - there is a strong downward shift at all latitudes in NO_CVTRANS and NO_LS_RO. There are also notable upward shifts from NO_CV_RO, NO_COND and (particularly at middle and high latitudes) NO_WETOX.

For sea salt, convective rainout has the largest effect on the vertical distribution (even though dry deposition dominates removal) - there is a strong upward shift at all latitudes in NO_CV_RO. Large-scale rainout takes over at high latitudes, with NO_LS_RO causing a similar shift there. Boundary-layer mixing also appears important, with NO_BLMIX showing a downward shift except at latitudes with relatively little ocean (Antarctica and the northern midlatitudes).

For black carbon and organic aerosol, the picture is a little more complex. BB_TROP/z shows a large upward shift, while BB_SURF shows only a small downward shift - this suggests that biomass-burning emissions are well mixed by the boundary-layer scheme and thus the emission profile only becomes important if it extends well into the free troposphere. This is borne out by the larger downward shift seen in NO_BLMIX. The effects of convective transport, rainout and condensation are similar to those for sulfate, with downward shifts from NO_CVTRANS and NO_LS_RO and upward shifts from NO_CV_RO and NO_COND. Ageing also plays a big role, as primary $\mathrm{BC} / \mathrm{OA}$ are emitted into the insol- 

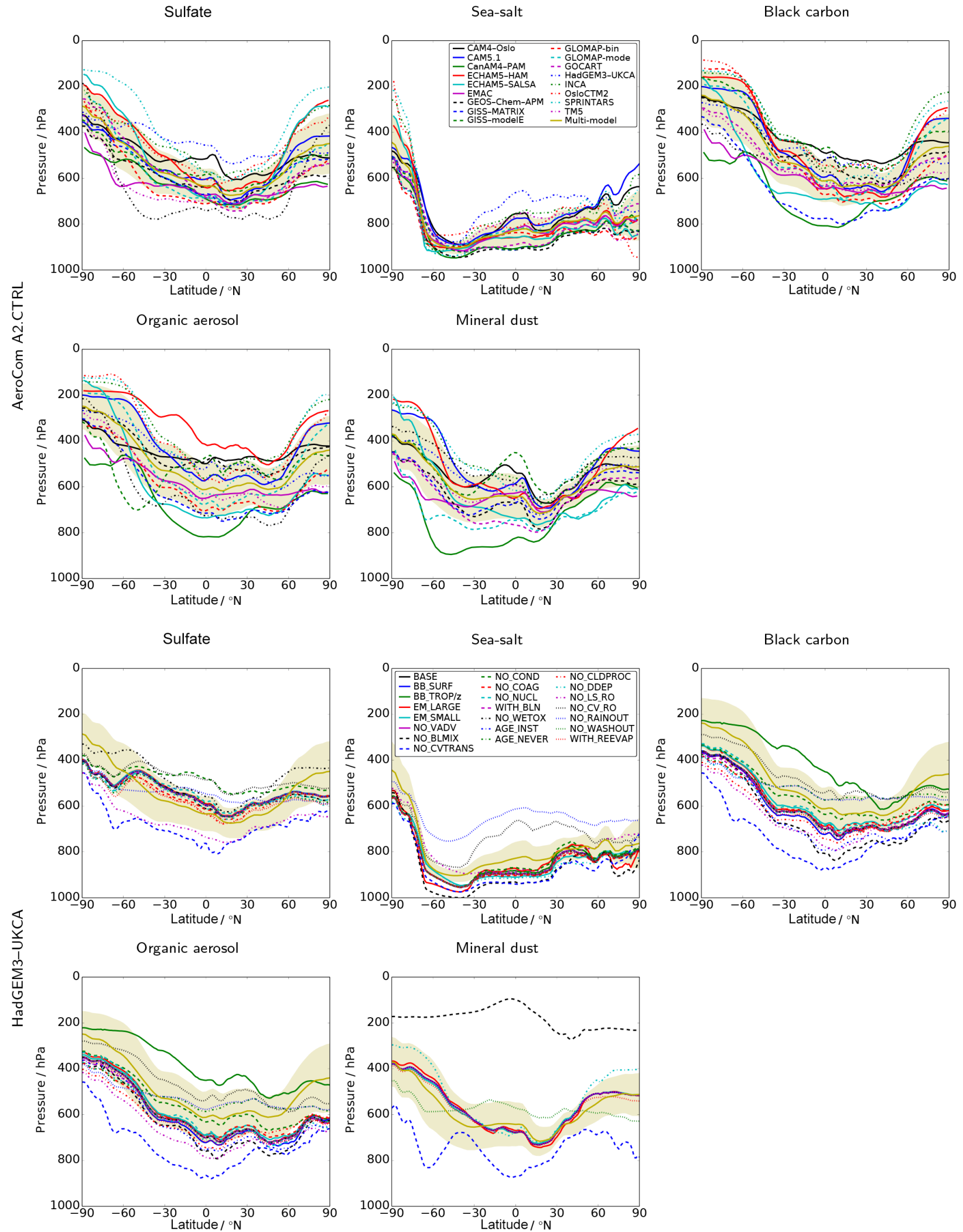

Figure 3. Annual- and zonal-mean mass-weighted mean pressure level (vertical centre of mass in pressure coordinates) of sulfate, sea salt, black carbon, organic aerosol and mineral dust from the AeroCom Phase II models (top) and HadGEM3-UKCA sensitivity-test simulations (bottom). The multi-model mean and standard deviation of the former are indicated by the yellow line and shading. 
Table 3. HadGEM3-UKCA simulations showing the strongest change (compared to BASE) in zonal-mean vertical centre of mass.

\begin{tabular}{|c|c|c|c|c|c|}
\hline Simulation & $\mathrm{SO}_{4}$ & SS & $\mathrm{BC}$ & $\mathrm{OA}$ & DU \\
\hline BB_TROP/z & & & $\Uparrow$ & $\Uparrow$ & \\
\hline NO_BLMIX & & $\downarrow$ & $\downarrow$ & $\downarrow$ & 0 \\
\hline NO_CVTRANS & $\Downarrow$ & $\downarrow$ & $\Downarrow$ & $\Downarrow$ & $\Downarrow$ \\
\hline NO_COND & $\uparrow$ & & $\uparrow$ & $\uparrow$ & \\
\hline NO_WETOX & $\uparrow \uparrow$ & & & & \\
\hline AGE_INST & & & $\downarrow$ & $\downarrow$ & \\
\hline AGE_NEVER & & & $\uparrow$ & $\uparrow$ & \\
\hline NO_DDEP & & & & & $\uparrow \uparrow$ \\
\hline NO_LS_RO & $\Downarrow$ & $\uparrow \uparrow$ & $\downarrow$ & $\downarrow$ & \\
\hline NO_CV_RO & $\uparrow$ & $\Uparrow$ & $\uparrow$ & $\uparrow$ & \\
\hline NO_RAINOUT & & $\Uparrow$ & $\uparrow$ & $\uparrow$ & \\
\hline NO_WASHOUT & & & & & $\uparrow$ \\
\hline
\end{tabular}

uble modes: AGE_INST (which will hasten removal) shows a downward shift, while AGE_NEVER shows an upward shift very similar to NO_RAINOUT (as expected since the aerosol never becomes soluble, and is thus not susceptible to in-cloud scavenging).

For mineral dust, boundary-layer mixing dominates the effects on the vertical profile - in NO_BLMIX, aerosol emitted at the surface is never mixed upwards and is immediately removed by dry deposition in the same time step due to the operator-splitting of emission and deposition in the model. There is thus virtually no mineral dust transported in the atmosphere of this simulation. (The high altitude shown in the plots is an artefact of the very small amount of dust still present from the starting state of the model - removal of the small dust particles from the tropopause layer is very slow, while the rest of the troposphere has been cleaned of dust during the spin-up period.) Convective transport also has a strong effect, with NO_CVTRANS producing a large downward shift at all latitudes. Dry deposition and washout (below-cloud impaction scavenging) also play a significant role - NO_DDEP shows an enhanced "U" shape (due to an upward shift at high latitudes), while NO_WASHOUT shows a flattening of the curve (due to both a downward shift at high latitudes and an upward shift in the tropics).

The simulations showing the strongest shifts in vertical position for each component are summarised in Table 3.

\subsection{Size-resolved CN profiles}

The annual- and global-mean vertical number profiles of $\mathrm{CN}$ larger than 3,30,100, and $500 \mathrm{~nm}$ diameter from our HadGEM3-UKCA process-sensitivity tests are shown in Fig. 4. There is a steady progression as we move from smaller to larger diameters: for most configurations, the global-mean profiles go from peaking strongly in the tropopause layer to fairly well mixed in the vertical, and then to peaking near the surface.

The zonal-mean vertical position of $\mathrm{CN}$ larger than each of these diameters (as represented by the number-weighted mean pressure level) is shown in Fig. 5. Again, the progression in size can be seen, with smaller diameters showing a humped shape with their highest average position in the tropics, while larger diameters show a "U" shape similar to that seen for component masses in many of the AeroCom models, with their highest position towards the poles. For CN larger than $30 \mathrm{~nm}$, the meridional profile of vertical position is almost flat.

For the smallest (and most numerous) particles that dominate $\mathrm{CN}>3 \mathrm{~nm}$, the strongest effects are seen from the microphysical processes. NO_NUCL reduces the number of particles at all levels, but especially (and by several orders of magnitude) in the tropopause layer, where most nucleation occurs - thus producing a strong downward shift in mean position (Fig. 5), which is strongest in the tropics, reversing the humped shape shown in BASE. NO_COND also produces a strong downward shift, but by a different route leaving the tropical "hump" intact - particle numbers increase at all levels, but especially in the lower troposphere, where the condensation sink normally suppresses nucleation. NO_COAG results in a very high mean vertical position at all latitudes, although the global-mean profile does not change shape much but the particle count increases by about an order of magnitude at all levels. WITH_BLN increases the particle number in the lower troposphere, causing a downward shift in mean position, especially in the mid-latitudes. In addition to microphysical processes, NO_RAINOUT causes a downward shift even though $\mathrm{CN}>3 \mathrm{~nm}$ is dominated by particles too small to be activated as $\mathrm{CCN}$; the effect from NO_LS_RO or NO_CV_RO alone is rather small, however. (Although there are no changes to the scavenging of gasphase aerosol precursors in any of these simulations, the scavenging of larger particles will affect the condensation sink and consequently the nucleation and coagulation rates.) A modest downward shift at all latitudes is also seen from EM_SMALL, which increases particle numbers in the lower troposphere, where most emissions are injected.

Looking at only the larger particles $(\mathrm{CN}>100 \mathrm{~nm})$ that may act as $\mathrm{CCN}$ if they have a soluble component, the picture is somewhat changed. Convective transport becomes very important, with NO_CVTRANS producing the largest downward shift of all. Wet deposition also becomes much more important in this size range, with 

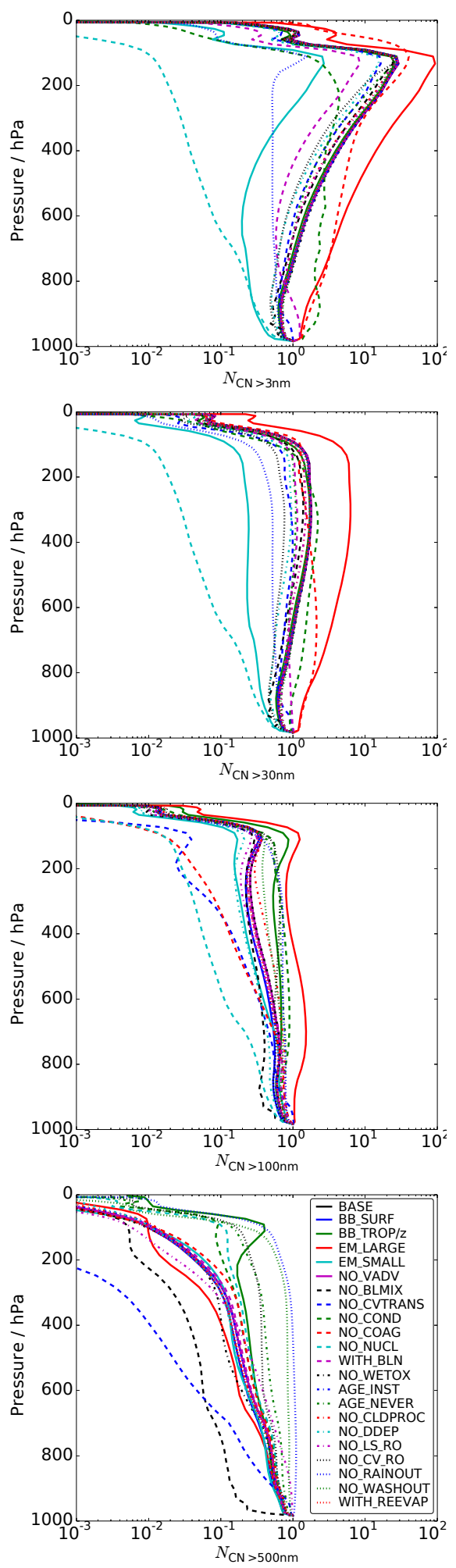

Figure 4. Annual- and global-mean vertical profiles of condensation nuclei $(\mathrm{CN})$ above $3,30,100$ and $500 \mathrm{~nm}$ dry diameter from the HadGEM3-UKCA sensitivity-test simulations, normalised to the mixing ratio at the surface.
NO_LS_RO showing a downward shift at all latitudes, while NO_CV_RO shows an upward shift in the tropics; these combine in NO_RAINOUT to give a largely flat meridional profile. There is also now a (weaker) flattening from NO_WASHOUT, and a small downward shift at all latitudes from NO_DDEP as particles collect in the lowest layer. Primary emission height and size distribution, and ageing, also become important, with $\mathrm{BB} \_\mathrm{TROP} / \mathrm{z}$ showing an upward shift, EM_LARGE and EM_SMALL showing an upward and a downward shift respectively, and AGE_NEVER showing a flattening of the meridional profile. Microphysics remain important, with NO_NUCL still reducing particle numbers at all levels and causing a downward shift, although less dramatically than at smaller sizes, while WITH_BLN no longer has much effect at all. NO_COND shows a much more modest increase in particle numbers than at smaller sizes, and acts to flatten the "U" shape of the meridional profile, mostly by an upward shift in the tropics. At these larger sizes, NO_COAG reduces the particle number especially at higher levels, leading to a downward shift at all latitudes.

At the largest sizes (for $\mathrm{CN}>500 \mathrm{~nm}$ ), the picture changes again. Convective transport remains the strongest effect, with NO_CVTRANS producing the largest downward shift. The impact of wet deposition processes becomes even stronger, with NO_LS_RO, NO_CV_RO, NO_RAINOUT and NO_WASHOUT all dramatically increasing the total number of particles; NO_LS_RO concentrates the profile towards the surface, giving a downward shift at most latitudes, while the other processes show an upward shift making both the global vertical profile and meridional profile of vertical position more uniform. The impact of biomass-burning emission profiles becomes much stronger, with $\mathrm{BB} \_\mathrm{TROP} / \mathrm{z}$ showing a pronounced peak in the global vertical profile around the tropopause and an upward shift concentrated in the $50^{\circ} \mathrm{S}-10^{\circ} \mathrm{N}$ latitude range. Primary particle size continues to be important, as do ageing and microphysics. Aqueous chemistry, boundary-layer mixing and re-evaporation also start to have an effect: NO_WETOX shows a downward shift in the Southern Hemisphere; NO_BLMIX shows a downward shift in the tropics and Northern Hemisphere for $\mathrm{CN}>500 \mathrm{~nm}$ (likely due to the increasing contribution of mineral dust to the particle count at larger sizes); and WITH_REEVAP shows a small downward shift at all latitudes.

A number of the processes make little difference to any of the number profiles: BB_SURF, AGE_INST, and NO_VADV all look very similar to BASE.

\subsection{Normalised direct radiative forcing}

The AOD-normalised radiative forcing (NRFA) due to anthropogenic aerosol in each of the HadGEM3-UKCA configurations is shown in Fig. 6, along with the absolute DRF and anthropogenic change in AOD from which NRFA is calculated. The spread in absolute DRF is much larger than 

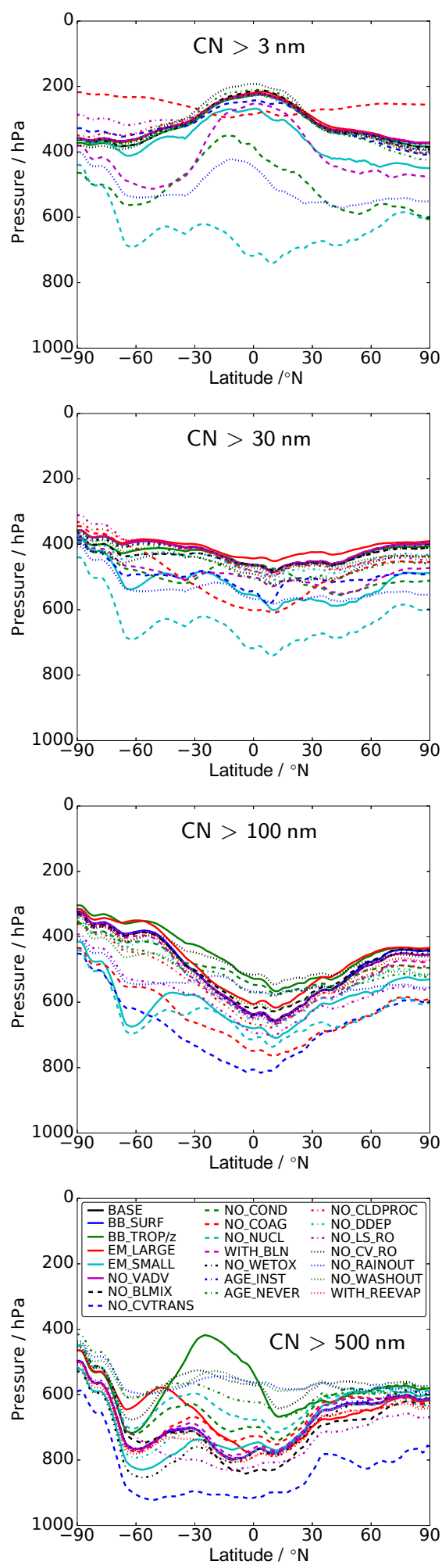

Figure 5. Annual- and zonal-mean number-weighted mean pressure level (vertical centre of number in pressure coordinates) of condensation nuclei $(\mathrm{CN})$ above 3, 30, 100 and $500 \mathrm{~nm}$ dry diameter from the HadGEM3-UKCA sensitivity-test simulations.

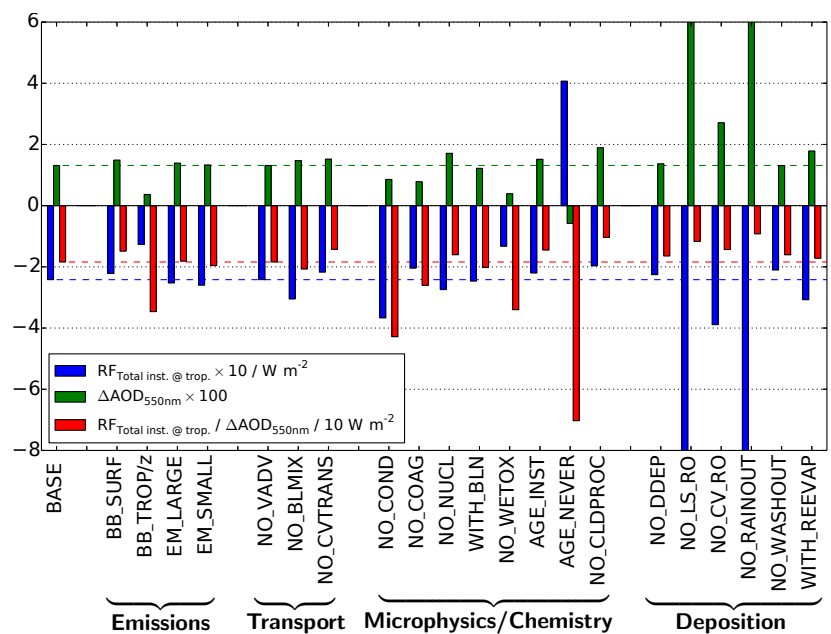

Figure 6. Annual- and global-mean direct radiative forcing (DRF), change in AOD, and AOD-normalised DRF, due to anthropogenic aerosol, for each of the HadGEM3-UKCA configurations. The dashed lines represent the values from the BASE simulation to aid comparison. Note that, to fit on the same scale, the AOD has been multiplied by 100 and the absolute and normalised DRF in $\mathrm{W} \mathrm{m}^{-2}$ have been multiplied and divided by 10 respectively.

that seen in the AeroCom experiments (Schulz et al., 2006; Myhre et al., 2013), due to the fact that the sensitivity tests presented here are not physically realistic as they omit certain processes by design leading to large changes in the total aerosol load in some cases.

The NRFA becomes much more strongly negative in NO_COND (where the absolute DRF is also stronger), BB_TROP/z and NO_WETOX (where $\triangle \mathrm{AOD}$ is reduced), and especially in AGE_NEVER (where the sign of both $\triangle \mathrm{AOD}$ and the absolute DRF is reversed); a more modest strengthening is seen in NO_COAG (due to reduced $\triangle \mathrm{AOD}$ ).

The NRFA becomes much weaker in NO_CLDPROC (where the absolute DRF is also weaker), and also in NO_LS_RO and NO_RAINOUT (where the large increase in $\triangle \mathrm{AOD}$ overcompensates for the stronger absolute DRF); a more modest weakening is seen in BB_SURF (due to weaker absolute DRF), and also in NO_CV_RO (due to increased $\triangle \mathrm{AOD}$ ) and NO_CVTRANS (due to both).

The smaller effects seen in EM_SMALL, NO_BLMIX, NO_NUCL, WITH_BLN, NO_DDEP, NO_WASHOUT and WITH_REEVAP are unlikely to be significant on the global scale, but it is possible that they may have a greater impact regionally.

\section{Discussion}

Although the overall inter-model spread of the AeroCom A2.CTRL global-mean vertical profiles is well covered by the spread of profiles from our HadGEM3-UKCA processsensitivity tests (Fig. 1), the same is not true for the merid- 
ional variation in vertical position, where the spread from our simulations is typically narrower than that of the AeroCom models (Fig. 3). In addition, for most aerosol components none of the (fairly strongly perturbed) HadGEM3-UKCA simulations are able to reproduce either the strong "inverted $S$ " shape seen in the global-mean vertical profile of several of the AeroCom models, or the "U" shape in the meridional profile of vertical position by mass.

For sulfate, where nucleation and condensation provide a significant upper-troposphere source, a very weak version of the "inverted S" shape is seen in most of our simulations, but none of the configurations enhance the shape seen in BASE to anything approaching the shape seen in, for example, ECHAM5-HAM2. For black carbon and organic aerosol, we do see a similar but sharper shape in BB_TROP/z (where biomass-burning emissions are extended all the way to the tropopause). It is very unlikely that any realistic model would actually inject such emissions as high as this, but it is possible that emissions at a lower level followed by convective transport with weak scavenging and a high detrainment level might cause a similar effect. Although we consider the effect of switching off convective transport or scavenging in HadGEM3-UKCA, we have not tested the effect of changes to the convective parameterisation that might alter the vertical profile with which aerosol is detrained - such an experiment might shed further light on the mechanism by which this profile shape is generated.

In the case of sulfate, only NO_CVTRANS and NO_LS_RO are able to produce anything similar to the strongly decreasing vertical profile seen in several of the AeroCom models, although even in that simulation the profile remains rather uniform over the lower/middle troposphere. Coupled with the fact that NO_CV_RO shifts the profile in the other direction, making it even more uniform, this suggests that the treatment of wet deposition - in particular the vertical distribution of scavenging and the balance between large-scale and convective processes - and convective transport are the major factors controlling the vertical profile. The differing effects of these processes can be understood on the basis that large-scale precipitation predominantly removes aerosol from the lower troposphere, where large stratiform clouds are found at the top of the boundary layer, and hence turning this process off leads to an accumulation of extra aerosol at lower levels; convective precipitation, on the other hand, removes aerosol that would otherwise be rapidly transported to the middle and upper troposphere, and hence turning it off results in extra aerosol at upper levels.

We do see a "U" shape in the meridional profile of vertical position for mineral dust in HadGEM3-UKCA (which is transported by a separate scheme), but not for any of the other aerosol components that are included in UKCA. The only exception is for sulfate in the NO_WETOX simulation, where (presumably due to the loss of a major freetroposphere source of sulfate) such a shape does develop. This suggests that the occurrence of this shape may be re- lated to a variation in the strength or vertical profile of incloud sulfate production amongst the models. For carbonaceous aerosol, obtaining such a shape in HadGEM-UKCA would require increased aerosol aloft at high northern latitudes. This suggests that the processes controlling transport to, and lifting and removal within, the Arctic may be key to understanding this difference. Unlike the other components, dust emissions are heavily concentrated at low latitudes, which we would expect to cause the dust burden in the tropics to be dominated by freshly emitted dust near the surface.

The variation with particle size of the meridional profile of vertical position by number (Fig. 5) suggests the possibility that this " $U$ " shape (which is seen in the number profile of larger CN in HadGEM3, and inverted for smaller CN) might be related to the size distribution: shifting the balance from small nucleation- and Aitken-mode particles to larger accumulation-mode particles might produce more of a " $U$ " shape in the mass profiles. However, we do not see such an effect in NO_NUCL, where the lack of new-particle nucleation should produce such a shift in the size distribution.

Because the profile shapes vary considerably amongst the aerosol components, evaluation against the available observations (which in general cannot separate the components) is difficult. Nevertheless, CALIOP observations suggest that both decreasing-with-height and more S-shaped profiles do occur in certain regions and seasons (Koffi et al., 2012, Fig. 6). It seems likely that this relates to different balances of processes, in a similar way to the varying profiles in the model simulations.

For all aerosol components, only a minority of the processes show a significant effect on vertical position in HadGEM3-UKCA (although the specific processes that are important vary by component). Transport by large-scale vertical advection shows very little effect on the zonal-mean vertical position of any of the components by mass, or of $\mathrm{CN}$ at any size by number. This suggests that, at a typical global climate model resolution, vertical transport of aerosol is dominated by unresolved scales (i.e. convection and boundarylayer turbulence). There are further processes (nucleation, coagulation and emission size) that affect only the $\mathrm{CN}$ number profiles, while having very little effect on the component mass profiles.

The fact that several aspects of the inter-model diversity in vertical profiles are not reproduced by any of the sensitivity tests suggests that there are additional factors influencing the vertical distribution of aerosol. In particular, it appears likely that such factors are responsible for the difference between "U-shaped" and flatter meridional profiles, which was largely unreproducible in HadGEM3-UKCA in this study. It is possible that some of these variations could be explained by the interaction of two or more of the processes considered in this experiment, which might be identified by a more sophisticated approach in which multiple processes are perturbed at the same time. Alternatively, it may be that these 
variations are due to structural differences in the models that are simply not captured by the set of processes considered in this experiment. The parameterisation of convective transport is a likely candidate, as mentioned above, given its dominant role as illustrated by the NO_CVTRANS simulation; the tracer advection schemes used in different models may also vary in their numerical diffusivity. Models vary considerably in the sophistication of their treatments of secondary organic aerosol and boundary-layer nucleation, which may lead to diversity as suggested by Yu et al. (2010) which cannot be reproduced within HadGEM3-UKCA. In the particular case of mineral dust, many models permit it to be removed by in-cloud scavenging, which is not the case in HadGEM3UKCA.

From the changes in AOD and radiative forcing seen in Fig. 6, we can see that, of the processes that affect the vertical profile of aerosol, the ones that have the greatest potential impact on normalised direct radiative forcing are the extent of biomass-burning emissions into the free troposphere, condensation, production of sulfate by aqueous oxidation, ageing of insoluble particles, in-cloud scavenging, cloud processing and, to a lesser extent, coagulation and convective transport.

It should be acknowledged, however, that the dominant processes controlling the vertical profile are not necessarily the same in different models (e.g. a process which has little impact on the vertical profile in HadGEM3-UKCA may nevertheless have a strong impact in a different model). Parameterisations of a given process may vary in how they capture the effect on the vertical profile, and the balance of processes may well differ amongst models. Both of these factors, along with other structural differences between the models, will contribute to diversity both in the vertical profiles themselves and their sensitivity to different processes. It would therefore be informative to conduct similar experiments with a range of models to assess how model-specific these dominant processes are.

\section{Conclusions}

In this study, we investigate the impact of a wide range of processes on aerosol vertical distribution in the HadGEM3UKCA aerosol-climate model through a series of limitingcase process-based sensitivity tests. We show that the processes that have the greatest impact on the vertical distribution vary both between different aerosol components and over the particle size spectrum.

Convective transport, as the key mechanism for lifting aerosol out of the boundary layer, is very important for all components. In-cloud scavenging (both large-scale and convective) is important for all except mineral dust, which never ages to become soluble in HadGEM3. Growth of particles by condensation from the gas phase is important for sulfate and carbonaceous aerosol, with growth by aqueous oxida- tion also important for sulfate, especially at high latitudes. Ageing from insoluble to soluble (which controls the susceptibility to removal by in-cloud scavenging) is also important for carbonaceous aerosol. Boundary-layer mixing is of great importance for those components emitted purely at or near the surface (mineral dust and sea salt). Dry deposition and below-cloud scavenging affect only the profile of mineral dust (which includes very large particles, and is not removed by in-cloud scavenging in this model).

In terms of particle size, microphysical processes (nucleation, condensation and coagulation) are the dominant processes in terms of the vertical profile of the smallest and most numerous particles $(\mathrm{CN}>3 \mathrm{~nm})$, while convective transport, the size distribution and altitude of primary emissions, and removal processes, become progressively more important at larger sizes.

For the AOD-normalised direct radiative forcing, the strongest effects come mostly from processes that affect the vertical mass (as opposed to $\mathrm{CN}$ number) distribution: aqueous oxidation, ageing, in-cloud scavenging and the extent of biomass-burning emissions into the free troposphere. However, there are also effects from processes affecting the size distribution, in particular condensation and coagulation - this may be due to either their link to the ageing process or changes in the optical properties of the aerosol.

From studying the process sensitivity of the vertical profiles in a single model, we cannot determine whether the processes identified are universally the most important for controlling the vertical profile, or whether this varies amongst models. It would therefore be illuminating to conduct similar sensitivity tests with one or more other models, to establish the consistency (or otherwise) of the processes controlling the vertical profile.

We also compare the spread of vertical profiles from these HadGEM3-UKCA sensitivity-test simulations with the inter-model diversity from the AeroCom Phase II control experiment. This shows that, although these processes can produce a similar overall spread to that among the global-mean AeroCom profiles, there are certain features that none of our HadGEM3-UKCA simulations can reproduce: specifically an "inverted S" shape in the global mass profiles (where the vertical mass distribution has a secondary peak in mixing ratio in the upper troposphere), and a " $U$ " shape in the meridional profile of mass-weighted vertical position (where the centre of mass of aerosol is lower in the tropics than at higher latitudes). This suggests that there are additional structural differences between the AeroCom models that are important for controlling the vertical distribution, but which are not captured by the processes considered here (e.g. in tracer advection schemes, the parameterisation of convective transport or in-cloud scavenging of mineral dust). Identifying these structural differences may help to better understand the causes of the diversity among models, and thus to quantify and (with the help of observations) reduce the uncertainty in 
our modelling of aerosol vertical profiles and the resulting effects on Earth's climate.

\section{The Supplement related to this article is available online at doi:10.5194/acp-16-2221-2016-supplement.}

Acknowledgements. This work was supported by the Natural Environment Research Council project GASSP (grant number NE/J022624/1) and the Met Office. P. Stier would like to acknowledge funding from the European Research Council under the European Union's Seventh Framework Programme (FP7/20072013)/ERC grant agreement no. FP7-280025. G. W. Mann was supported by the Natural Environment Research Council (NERC) through the National Centre for Atmospheric Science (NCAS). T. Bergman and H. Kokkola were supported by the Academy of Finland Centre of Excellence (project no. 272041). S. Ghan and $X$. Liu were supported by the US Department of Energy Office of Science Decadal and Regional Climate Prediction using Earth System Models (EaSM) programme. The Pacific Northwest National Laboratory (PNNL) is operated for the DOE by Battelle Memorial Institute under contract DE-AC06-76RLO 1830. A. Kirkevåg, T. Iversen and $\varnothing$. Seland (CAM4-Oslo) were supported by the Research Council of Norway through the EarthClim (207711/E10), EVA (229771) and NOTUR/NorStore projects, by the Norwegian Space Centre through PM-VRAE, and through the EU projects PEGASOS and ACCESS. K. von Salzen was supported by the Canadian Foundation for Climate and Atmospheric Sciences (CFCAS) and Environment Canada. R. B. Skeie (OsloCTM2) was supported by the Research Council of Norway, through the grants SLAC, AEROCOM-P3 and ClimSense. T. Takemura was supported by the supercomputer system of the National Institute for Environmental Studies, Japan, the Environment Research and Technology Development Fund (S-12-3) of the Ministry of the Environment, Japan, and JSPS KAKENHI (grant numbers 15H01728 and 15K12190). K. Tsigaridis and S. E. Bauer were supported by NASA-MAP (NASA award number: NNX09AK32G). Resources supporting this work were provided by the NASA High-End Computing (HEC) Program through the NASA Center for Climate Simulation (NCCS) at Goddard Space Flight Center. K. Zhang was supported by funding from the Max Planck Society. Simulations with ECHAM5HAM2 were performed at the German Climate Computing Center (Deutsches Klimarechenzentrum GmbH, DKRZ).

ERA-Interim data provided by Paul Berrisford and the European Centre for Medium-Range Weather Forecasts (ECMWF). The development of GLOMAP-mode within HadGEM is part of the UKCA project, which is supported by both NERC and the Joint DECC/DEFRA Met Office Hadley Centre Climate Programme. We acknowledge use of the MONSooN system, a collaborative facility supplied under the Joint Weather and Climate Research Programme, a strategic partnership between the Met Office and the Natural Environment Research Council.

Edited by: B. Ervens

\section{References}

Albrecht, B. A.: Aerosols, cloud microphysics, and fractional cloudiness, Science, 245, 1227-1230, 1989.

Andres, R. J. and Kasgnoc, A. D.: A time-averaged inventory of subaerial volcanic sulfur emissions, J. Geophys. Res., 103, 25251-25261, doi:10.1029/98JD02091, 1998.

Ångström, A.: Atmospheric turbidity, global illumination and planetary albedo of the earth, Tellus, 14, 435-450, doi:10.1111/j.2153-3490.1962.tb01356.x, 1962.

Bauer, S. E., Wright, D. L., Koch, D., Lewis, E. R., McGraw, R., Chang, L.-S., Schwartz, S. E., and Ruedy, R.: MATRIX (Multiconfiguration Aerosol TRacker of mIXing state): an aerosol microphysical module for global atmospheric models, Atmos. Chem. Phys., 8, 6003-6035, doi:10.5194/acp-8-60032008, 2008.

Bauer, S. E., Bausch, A., Nazarenko, L., Tsigaridis, K., Xu, B., Edwards, R., Bisiaux, M., and McConnell, J.: Historical and future black carbon deposition on the three ice caps: ice core measurements and model simulations from 1850 to 2100 , J. Geophys. Res., 118, 7948-7961, doi:10.1002/jgrd.50612, 2013.

Beard, K. V. and Grover, S. N.: Numerical collision efficiencies for small raindrops colliding with micron size particles, J. Atmos. Sci., 31, 543-550, doi:10.1175/15200469(1974)031<0543:NCEFSR>2.0.CO;2, 1974.

Bellouin, N.: Interaction of UKCA aerosols with radiation: UKCA RADAER, Internal report, Met. Office, Exeter, UK, available at: http://www.ukca.ac.uk/ukca/images/d/dc/UKCA_RADAER. pdf (last access: 18 September 2015), 13 pp., 2010.

Bellouin, N., Boucher, O., Haywood, J., Johnson, C., Jones, A., Rae, J., and Woodward, S.: Improved representation of aerosols for HadGEM2, Hadley Centre Technical Note 73, Met. Office, Exeter, UK, available at: https://digital.nmla.metoffice.gov.uk/download/file/sdb\% 3AdigitalFile\%7C5cbfa153-e186-4b67-9028-a160d7cb33a5/ (last access: 18 September 2015), 43 pp., 2007.

Bellouin, N., Mann, G. W., Woodhouse, M. T., Johnson, C., Carslaw, K. S., and Dalvi, M.: Impact of the modal aerosol scheme GLOMAP-mode on aerosol forcing in the Hadley Centre Global Environmental Model, Atmos. Chem. Phys., 13, 30273044, doi:10.5194/acp-13-3027-2013, 2013.

Bergman, T., Kerminen, V.-M., Korhonen, H., Lehtinen, K. J., Makkonen, R., Arola, A., Mielonen, T., Romakkaniemi, S., Kulmala, M., and Kokkola, H.: Evaluation of the sectional aerosol microphysics module SALSA implementation in ECHAM5HAM aerosol-climate model, Geosci. Model Dev., 5, 845-868, doi:10.5194/gmd-5-845-2012, 2012.

Chin, M., Rood, R. B., Lin, S.-J., Müller, J.-F., and Thompson, A. M.: Atmospheric sulfur cycle simulated in the global model GOCART: model description and global properties, J. Geophys. Res., 105, 24671-24687, doi:10.1029/2000JD900384, 2000.

Collins, W. J., Bellouin, N., Doutriaux-Boucher, M., Gedney, N., Hinton, T., Jones, C. D., Liddicoat, S., Martin, G., O’Connor, F., Rae, J., Senior, C., Totterdell, I., Woodward, S., Reichler, T., and Kim, J.: Evaluation of the HadGEM2 model, Hadley Centre Technical Note 74, Met. Office, Exeter, UK, available at: https://digital.nmla.metoffice.gov.uk/download/file/sdb\% 3AdigitalFile\%7C208ab2dd-2f97-4b1a-91cd-a68fd30e5ae9/ (last access: 18 September 2015), 47 pp., 2008. 
Davies, T.: A new dynamical core of the Met Office's global and regional modelling of the atmosphere, Q. J. Roy. Meteor. Soc., 131, 1759-1782, doi:10.1256/qj.04.101, 2005.

Dee, D. P., Uppala, S. M., Simmons, A. J., Berrisford, P., Poli, P., Kobayashi, S., Andrae, U., Balmaseda, M. A., Balsamo, G., Bauer, P., Bechtold, P., Beljaars, A. C. M., van de Berg, L., Bidlot, J., Bormann, N., Delsol, C., Dragani, R., Fuentes, M., Geer, A. J., Haimberger, L., Healy, S. B., Hersbach, H., Hólm, E. V., Isaksen, L., Kållberg, P., Köhler, M., Matricardi, M., McNally, A. P., Monge-Sanz, B. M., Morcrette, J.-J., Park, B.K., Peubey, C., de Rosnay, P., Tavolato, C., Thépaut, J.-N., and Vitart, F.: The ERA-Interim reanalysis: configuration and performance of the data assimilation system, Q. J. Roy. Meteor. Soc., 137, 553-597, doi:10.1002/qj.828, 2011.

Dentener, F., Kinne, S., Bond, T., Boucher, O., Cofala, J., Generoso, S., Ginoux, P., Gong, S., Hoelzemann, J. J., Ito, A., Marelli, L., Penner, J. E., Putaud, J.-P., Textor, C., Schulz, M., van der Werf, G. R., and Wilson, J.: Emissions of primary aerosol and precursor gases in the years 2000 and 1750 prescribed data-sets for AeroCom, Atmos. Chem. Phys., 6, 43214344, doi:10.5194/acp-6-4321-2006, 2006.

Diehl, T., Heil, A., Chin, M., Pan, X., Streets, D., Schultz, M., and Kinne, S.: Anthropogenic, biomass burning, and volcanic emissions of black carbon, organic carbon, and $\mathrm{SO}_{2}$ from 1980 to 2010 for hindcast model experiments, Atmos. Chem. Phys. Discuss., 12, 24895-24954, doi:10.5194/acpd-12-24895-2012, 2012.

Easter, R. C. and Hales, J. M.: Interpretation of the OSCAR data for reactive gas scavenging, in: Precipitation Scavenging, Dry Deposition, and Resuspension, edited by: Pruppacher, H. R., Semonin, R. G., and Slinn, W. G. N., Elsevier, New York, 649-662, 1983.

Fuchs, N. A. and Sutugin, A. G.: Highly dispersed aerosols, in: Topics in Current Aerosol Research, Vol. 2 of International Reviews in Aerosol Physics and Chemistry, edited by: Hidy, G. M. and Brock, J. R., Pergamon Press, New York, 1-60, 1971.

García, O. E., Díaz, J. P., Expósito, F. J., Díaz, A. M., Dubovik, O., Derimian, Y., Dubuisson, P., and Roger, J.-C.: Shortwave radiative forcing and efficiency of key aerosol types using AERONET data, Atmos. Chem. Phys., 12, 5129-5145, doi:10.5194/acp-125129-2012, 2012.

Ginoux, P., Chin, M., Tegen, I., Prospero, J. M., Holben, B., Dubovik, O., and Lin, S.-J.: Sources and distributions of dust aerosols simulated with the GOCART model, J. Geophys. Res., 106, 20255-20273, doi:10.1029/2000JD000053, 2001.

Gong, S. L.: A parameterization of sea-salt aerosol source function for sub- and super-micron particles, Global Biogeochem. Cy., 17, 1097, doi:10.1029/2003GB002079, 2003.

Gregory, D. and Rowntree, P. R.: A mass flux convection scheme with representation of cloud ensemble characteristics and stability-dependent closure, Mon. Weather Rev., 118, 1483-1506, doi:10.1175/15200493(1990)118<1483:AMFCSW>2.0.CO;2, 1990.

Hansen, J., Sato, M., and Ruedy, R.: Radiative forcing and climate response, J. Geophys. Res., 102, 6831-6864, doi:10.1029/96JD03436, 1997.

Hewitt, H. T., Copsey, D., Culverwell, I. D., Harris, C. M., Hill, R. S. R., Keen, A. B., McLaren, A. J., and Hunke, E. C.: Design and implementation of the infrastructure of HadGEM3: the next-generation Met Office climate modelling system, Geosci. Model Dev., 4, 223-253, doi:10.5194/gmd-4-223-2011, 2011.

Jeuken, A. B. M., Siegmund, P. C., Heijboer, L. C., Feichter, J., and Bengtsson, L.: On the potential of assimilating meteorological analyses in a global climate model for the purpose of model validation, J. Geophys. Res., 101, 16939-16950, doi:10.1029/96JD01218, 1996.

Johnson, B. T., Shine, K. P., and Forster, P. M.: The semidirect aerosol effect: Impact of absorbing aerosols on marine stratocumulus, Q. J. Roy. Meteor. Soc., 130, 1407-1422, doi:10.1256/qj.03.61, 2004.

Jones, A. and Roberts, D. L.: An interactive DMS emissions scheme for the unified model, Hadley Centre Technical Note 47, Met. Office, Exeter, UK, available at: http://www.metoffice. gov.uk/archive/hadley-centre-technical-note-47 (last access: 18 September 2015), 14 pp., 2004.

Kettle, A. J., Andreae, M. O., Amouroux, D., Andreae, T. W., Bates, T. S., Berresheim, H., Bingemer, H., Boniforti, R., Curran, M. A. J., DiTullio, G. R., Helas, G., Jones, G. B., Keller, M. D., Kiene, R. P., Leck, C., Levasseur, M., Malin, G., Maspero, M., Matrai, P., McTaggart, A. R., Mihalopoulos, N., Nguyen, B. C., Novo, A., Putaud, J. P., Rapsomanikis, S., Roberts, G., Schebeske, G., Sharma, S., Simó, R., Staubes, R., Turner, S., and Uher, G.: A global database of sea surface dimethylsulfide (DMS) measurements and a procedure to predict sea surface DMS as a function of latitude, longitude, and month, Global Biogeochem. Cy., 13, 399-444, doi:10.1029/1999GB900004, 1999.

Kipling, Z., Stier, P., Schwarz, J. P., Perring, A. E., Spackman, J. R., Mann, G. W., Johnson, C. E., and Telford, P. J.: Constraints on aerosol processes in climate models from vertically-resolved aircraft observations of black carbon, Atmos. Chem. Phys., 13, 5969-5986, doi:10.5194/acp-13-5969-2013, 2013.

Kirkevåg, A., Iversen, T., Seland, Ø., Hoose, C., Kristjánsson, J. E., Struthers, H., Ekman, A. M. L., Ghan, S., Griesfeller, J., Nilsson, E. D., and Schulz, M.: Aerosol-climate interactions in the Norwegian Earth System Model - NorESM1-M, Geosci. Model Dev., 6, 207-244, doi:10.5194/gmd-6-207-2013, 2013.

Koch, D. and Del Genio, A. D.: Black carbon semi-direct effects on cloud cover: review and synthesis, Atmos. Chem. Phys., 10, 7685-7696, doi:10.5194/acp-10-7685-2010, 2010.

Koch, D., Bond, T. C., Streets, D., Unger, N., and van der Werf, G. R.: Global impacts of aerosols from particular source regions and sectors, J. Geophys. Res., 112, D02205, doi:10.1029/2005JD007024, 2007.

Koffi, B., Schulz, M., Bréon, F.-M., Griesfeller, J., Winker, D., Balkanski, Y., Bauer, S., Berntsen, T., Chin, M., Collins, W. D., Dentener, F., Diehl, T., Easter, R., Ghan, S., Ginoux, P., Gong, S., Horowitz, L. W., Iversen, T., Kirkevåg, A., Koch, D., Krol, M., Myhre, G., Stier, P., and Takemura, T.: Application of the CALIOP layer product to evaluate the vertical distribution of aerosols estimated by global models: AeroCom phase I results, J. Geophys. Res., 117, D10201, doi:10.1029/2011JD016858, 2012.

Kulmala, M., Laaksonen, A., and Pirjola, L.: Parameterizations for sulfuric acid/water nucleation rates, J. Geophys. Res., 103, 83018307, doi:10.1029/97JD03718, 1998.

Kulmala, M., Lehtinen, K. E. J., and Laaksonen, A.: Cluster activation theory as an explanation of the linear dependence between 
formation rate of $3 \mathrm{~nm}$ particles and sulphuric acid concentration, Atmos. Chem. Phys., 6, 787-793, doi:10.5194/acp-6-787-2006, 2006.

Lamarque, J.-F., Bond, T. C., Eyring, V., Granier, C., Heil, A., Klimont, Z., Lee, D., Liousse, C., Mieville, A., Owen, B., Schultz, M. G., Shindell, D., Smith, S. J., Stehfest, E., Van Aardenne, J., Cooper, O. R., Kainuma, M., Mahowald, N., McConnell, J. R., Naik, V., Riahi, K., and van Vuuren, D. P.: Historical (1850-2000) gridded anthropogenic and biomass burning emissions of reactive gases and aerosols: methodology and application, Atmos. Chem. Phys., 10, 7017-7039, doi:10.5194/acp10-7017-2010, 2010.

Lee, L. A., Carslaw, K. S., Pringle, K. J., Mann, G. W., and Spracklen, D. V.: Emulation of a complex global aerosol model to quantify sensitivity to uncertain parameters, Atmos. Chem. Phys., 11, 12253-12273, doi:10.5194/acp-11-12253-2011, 2011.

Lee, L. A., Carslaw, K. S., Pringle, K. J., and Mann, G. W.: Mapping the uncertainty in global CCN using emulation, Atmos. Chem. Phys., 12, 9739-9751, doi:10.5194/acp-12-9739-2012, 2012.

Lee, L. A., Pringle, K. J., Reddington, C. L., Mann, G. W., Stier, P., Spracklen, D. V., Pierce, J. R., and Carslaw, K. S.: The magnitude and causes of uncertainty in global model simulations of cloud condensation nuclei, Atmos. Chem. Phys., 13, 8879-8914, doi:10.5194/acp-13-8879-2013, 2013.

Liu, X., Easter, R. C., Ghan, S. J., Zaveri, R., Rasch, P., Shi, X., Lamarque, J.-F., Gettelman, A., Morrison, H., Vitt, F., Conley, A., Park, S., Neale, R., Hannay, C., Ekman, A. M. L., Hess, P., Mahowald, N., Collins, W., Iacono, M. J., Bretherton, C. S., Flanner, M. G., and Mitchell, D.: Toward a minimal representation of aerosols in climate models: description and evaluation in the Community Atmosphere Model CAM5, Geosci. Model Dev., 5, 709-739, doi:10.5194/gmd-5-709-2012, 2012.

Lohmann, U. and Feichter, J.: Global indirect aerosol effects: a review, Atmos. Chem. Phys., 5, 715-737, doi:10.5194/acp-5-7152005, 2005.

Mann, G. W., Carslaw, K. S., Spracklen, D. V., Ridley, D. A., Manktelow, P. T., Chipperfield, M. P., Pickering, S. J., and Johnson, C. E.: Description and evaluation of GLOMAP-mode: a modal global aerosol microphysics model for the UKCA composition-climate model, Geosci. Model Dev., 3, 519-551, doi:10.5194/gmd-3-519-2010, 2010.

Mann, G. W., Johnson, C. E., Bellouin, N., Dalvi, M., Abraham, L., Carslaw, K. S., Boucher, O., Stier, P., Rae, J., Spracklen, D. V., Telford, P., Pyle, J. A., O’Connor, F., Carver, G., Pringle, K. J., and Woodhouse, M. T.: Evaluation of the new UKCA climatecomposition model. Part 3: Tropospheric aerosol properties, in preparation, 2016.

Marticorena, B. and Bergametti, G.: Modeling the atmospheric dust cycle: 1. Design of a soil-derived dust emission scheme, J. Geophys. Res., 100, 16415-16430, doi:10.1029/95JD00690, 1995.

McGraw, R.: Description of aerosol dynamics by the quadrature method of moments, Aerosol Sci. Tech., 27, 255-265, doi:10.1080/02786829708965471, 1997.

Myhre, G., Bellouin, N., Berglen, T. F., Berntsen, T. K., Boucher, O., Grini, A., Isaksen, I. S. A., Johnsrud, M., Mishchenko, M. I., Stordal, F., and Tanré, D.: Comparison of the radiative properties and direct radiative effect of aerosols from a global aerosol model and remote sensing data over ocean,
Tellus B, 59, 115-129, doi:10.1111/j.1600-0889.2006.00226.x, 2007.

Myhre, G., Berglen, T. F., Johnsrud, M., Hoyle, C. R., Berntsen, T. K., Christopher, S. A., Fahey, D. W., Isaksen, I. S. A., Jones, T. A., Kahn, R. A., Loeb, N., Quinn, P., Remer, L., Schwarz, J. P., and Yttri, K. E.: Modelled radiative forcing of the direct aerosol effect with multi-observation evaluation, Atmos. Chem. Phys., 9, 1365-1392, doi:10.5194/acp-91365-2009, 2009.

Myhre, G., Samset, B. H., Schulz, M., Balkanski, Y., Bauer, S., Berntsen, T. K., Bian, H., Bellouin, N., Chin, M., Diehl, T., Easter, R. C., Feichter, J., Ghan, S. J., Hauglustaine, D., Iversen, T., Kinne, S., Kirkevåg, A., Lamarque, J.-F., Lin, G., Liu, X., Lund, M. T., Luo, G., Ma, X., van Noije, T., Penner, J. E., Rasch, P. J., Ruiz, A., Seland, Ø., Skeie, R. B., Stier, P., Takemura, T., Tsigaridis, K., Wang, P., Wang, Z., Xu, L., Yu, H., Yu, F., Yoon, J.-H., Zhang, K., Zhang, H., and Zhou, C.: Radiative forcing of the direct aerosol effect from AeroCom Phase II simulations, Atmos. Chem. Phys., 13, 18531877, doi:10.5194/acp-13-1853-2013, 2013.

O'Connor, F. M., Johnson, C. E., Morgenstern, O., Abraham, N. L., Braesicke, P., Dalvi, M., Folberth, G. A., Sanderson, M. G., Telford, P. J., Voulgarakis, A., Young, P. J., Zeng, G., Collins, W. J., and Pyle, J. A.: Evaluation of the new UKCA climate-composition model - Part 2: The Troposphere, Geosci. Model Dev., 7, 41-91, doi:10.5194/gmd-7-41-2014, 2014.

Peng, Y., von Salzen, K., and Li, J.: Simulation of mineral dust aerosol with Piecewise Log-normal Approximation (PLA) in CanAM4-PAM, Atmos. Chem. Phys., 12, 6891-6914, doi:10.5194/acp-12-6891-2012, 2012.

Peters, K., Quaas, J., and Bellouin, N.: Effects of absorbing aerosols in cloudy skies: a satellite study over the Atlantic Ocean, Atmos. Chem. Phys., 11, 1393-1404, doi:10.5194/acp-11-13932011, 2011.

Pozzer, A., de Meij, A., Pringle, K. J., Tost, H., Doering, U. M., van Aardenne, J., and Lelieveld, J.: Distributions and regional budgets of aerosols and their precursors simulated with the EMAC chemistry-climate model, Atmos. Chem. Phys., 12, 961987, doi:10.5194/acp-12-961-2012, 2012.

Pringle, K. J., Tost, H., Message, S., Steil, B., Giannadaki, D., Nenes, A., Fountoukis, C., Stier, P., Vignati, E., and Lelieveld, J.: Description and evaluation of GMXe: a new aerosol submodel for global simulations (v1), Geosci. Model Dev., 3, 391-412, doi:10.5194/gmd-3-391-2010, 2010.

Riahi, K., Rao, S., Krey, V., Cho, C., Chirkov, V., Fischer, G., Kindermann, G., Nakicenovic, N., and Rafaj, P.: RCP 8.5 - a scenario of comparatively high greenhouse gas emissions, Climatic Change, 109, 33-57, doi:10.1007/s10584-011-0149-y, 2011.

Roeckner, E., Stier, P., Feichter, J., Kloster, S., Esch, M., and Fischer-Bruns, I.: Impact of carbonaceous aerosol emissions on regional climate change, Clim. Dynam., 27, 553-571, doi:10.1007/s00382-006-0147-3, 2006.

Samset, B. H. and Myhre, G.: Vertical dependence of black carbon, sulphate and biomass burning aerosol radiative forcing, Geophys. Res. Lett., 38, L24802, doi:10.1029/2011GL049697, 2011.

Samset, B. H., Myhre, G., Schulz, M., Balkanski, Y., Bauer, S., Berntsen, T. K., Bian, H., Bellouin, N., Diehl, T., Easter, R. C., Ghan, S. J., Iversen, T., Kinne, S., Kirkevåg, A., Lamarque, J.-F., Lin, G., Liu, X., Penner, J. E., Seland, Ø., Skeie, R. B., Stier, P., 
Takemura, T., Tsigaridis, K., and Zhang, K.: Black carbon vertical profiles strongly affect its radiative forcing uncertainty, Atmos. Chem. Phys., 13, 2423-2434, doi:10.5194/acp-13-24232013, 2013.

Samset, B. H., Myhre, G., Herber, A., Kondo, Y., Li, S.-M., Moteki, N., Koike, M., Oshima, N., Schwarz, J. P., Balkanski, Y., Bauer, S. E., Bellouin, N., Berntsen, T. K., Bian, H., Chin, M., Diehl, T., Easter, R. C., Ghan, S. J., Iversen, T., Kirkevåg, A., Lamarque, J.-F., Lin, G., Liu, X., Penner, J. E., Schulz, M., Seland, Ø., Skeie, R. B., Stier, P., Takemura, T., Tsigaridis, K., and Zhang, K.: Modelled black carbon radiative forcing and atmospheric lifetime in AeroCom Phase II constrained by aircraft observations, Atmos. Chem. Phys., 14, 12465-12477, doi:10.5194/acp-14-12465-2014, 2014.

Schulz, M., Textor, C., Kinne, S., Balkanski, Y., Bauer, S., Berntsen, T., Berglen, T., Boucher, O., Dentener, F., Guibert, S., Isaksen, I. S. A., Iversen, T., Koch, D., Kirkevåg, A., Liu, X., Montanaro, V., Myhre, G., Penner, J. E., Pitari, G., Reddy, S., Seland, Ø., Stier, P., and Takemura, T.: Radiative forcing by aerosols as derived from the AeroCom present-day and pre-industrial simulations, Atmos. Chem. Phys., 6, 5225-5246, doi:10.5194/acp-6-5225-2006, 2006.

Schwarz, J. P., Spackman, J. R., Gao, R. S., Watts, L. A., Stier, P., Schulz, M., Davis, S. M., Wofsy, S. C., and Fahey, D. W.: Global-scale black carbon profiles observed in the remote atmosphere and compared to models, Geophys. Res. Lett., 37, L18812, doi:10.1029/2010GL044372, 2010.

Schwarz, J. P., Samset, B. H., Perring, A. E., Spackman, J. R., Gao, R. S., Stier, P., Schulz, M., Moore, F. L., Ray, E. A., and Fahey, D. W.: Global-scale seasonally resolved black carbon vertical profiles over the Pacific, Geophys. Res. Lett., 40, 2013GL057775, doi:10.1002/2013GL057775, 2013.

Seinfeld, J. H. and Pandis, S. N.: Atmospheric Chemistry and Physics: From Air Pollution to Climate Change, WileyInterscience, New York, 1360 pp., 1998.

Sekhon, R. S. and Srivastava, R. C.: Doppler radar observations of drop-size distributions in a thunderstorm, J. Atmos. Sci., 28, 983-994, doi:10.1175/15200469(1971)028<0983:DROODS>2.0.CO;2, 1971.

Skeie, R. B., Berntsen, T. K., Myhre, G., Tanaka, K., Kvalevåg, M. M., and Hoyle, C. R.: Anthropogenic radiative forcing time series from pre-industrial times until 2010, Atmos. Chem. Phys., 11, 11827-11857, doi:10.5194/acp-1111827-2011, 2011.

Slinn, W. G. N.: Predictions for particle deposition to vegetative canopies, Atmos. Environ., 16, 1785-1794, doi:10.1016/00046981(82)90271-2, 1982.

Slinn, W. G. N.: Precipitation scavenging, in: Atmospheric Science and Power Production, edited by: Randerson, D., US Department of Energy, Springfield, VA, 466-532, 1984.

Spiro, P. A., Jacob, D. J., and Logan, J. A.: Global inventory of sulfur emissions with $1^{\circ} \times 1^{\circ}$ resolution, J. Geophys. Res., 97, 6023-6036, doi:10.1029/91JD03139, 1992.

Spracklen, D. V., Pringle, K. J., Carslaw, K. S., Chipperfield, M. P., and Mann, G. W.: A global off-line model of size-resolved aerosol microphysics: I. Model development and prediction of aerosol properties, Atmos. Chem. Phys., 5, 2227-2252, doi:10.5194/acp-5-2227-2005, 2005.
Stier, P., Feichter, J., Kinne, S., Kloster, S., Vignati, E., Wilson, J., Ganzeveld, L., Tegen, I., Werner, M., Balkanski, Y., Schulz, M., Boucher, O., Minikin, A., and Petzold, A.: The aerosol-climate model ECHAM5-HAM, Atmos. Chem. Phys., 5, 1125-1156, doi:10.5194/acp-5-1125-2005, 2005.

Takemura, T., Nozawa, T., Emori, S., Nakajima, T. Y., and Nakajima, T.: Simulation of climate response to aerosol direct and indirect effects with aerosol transport-radiation model, J. Geophys. Res., 110, D02202, doi:10.1029/2004JD005029, 2005.

Telford, P. J., Braesicke, P., Morgenstern, O., and Pyle, J. A.: Technical Note: Description and assessment of a nudged version of the new dynamics Unified Model, Atmos. Chem. Phys., 8, 17011712, doi:10.5194/acp-8-1701-2008, 2008.

Telford, P. J., Abraham, N. L., Archibald, A. T., Braesicke, P., Dalvi, M., Morgenstern, O., O’Connor, F. M., Richards, N. A. D., and Pyle, J. A.: Implementation of the Fast-JX Photolysis scheme (v6.4) into the UKCA component of the MetUM chemistry-climate model (v7.3), Geosci. Model Dev., 6, 161177, doi:10.5194/gmd-6-161-2013, 2013.

Textor, C., Schulz, M., Guibert, S., Kinne, S., Balkanski, Y., Bauer, S., Berntsen, T., Berglen, T., Boucher, O., Chin, M., Dentener, F., Diehl, T., Easter, R., Feichter, H., Fillmore, D., Ghan, S., Ginoux, P., Gong, S., Grini, A., Hendricks, J., Horowitz, L., Huang, P., Isaksen, I., Iversen, I., Kloster, S., Koch, D., Kirkevåg, A., Kristjansson, J. E., Krol, M., Lauer, A., Lamarque, J. F., Liu, X., Montanaro, V., Myhre, G., Penner, J., Pitari, G., Reddy, S., Seland, Ø., Stier, P., Takemura, T., and Tie, X.: Analysis and quantification of the diversities of aerosol life cycles within AeroCom, Atmos. Chem. Phys., 6, 1777-1813, doi:10.5194/acp-6-1777-2006, 2006.

Tsigaridis, K., Koch, D., and Menon, S.: Uncertainties and importance of sea spray composition on aerosol direct and indirect effects, J. Geophys. Res., 118, 220-235, doi:10.1029/2012JD018165, 2013.

Twomey, S.: The Influence of Pollution on the Shortwave Albedo of Clouds, J. Atmos. Sci., 34, 1149-1152, doi:10.1175/15200469(1977)034<1149:TIOPOT>2.0.CO;2, 1977.

van der Werf, G. R., Randerson, J. T., Giglio, L., Collatz, G. J., Mu, M., Kasibhatla, P. S., Morton, D. C., DeFries, R. S., Jin, Y., and van Leeuwen, T. T.: Global fire emissions and the contribution of deforestation, savanna, forest, agricultural, and peat fires (1997-2009), Atmos. Chem. Phys., 10, 11707-11735, doi:10.5194/acp-10-11707-2010, 2010.

van Noije, T. P. C., Le Sager, P., Segers, A. J., van Velthoven, P. F. J., Krol, M. C., Hazeleger, W., Williams, A. G., and Chambers, S. D.: Simulation of tropospheric chemistry and aerosols with the climate model EC-Earth, Geosci. Model Dev., 7, 24352475, doi:10.5194/gmd-7-2435-2014, 2014.

Vignati, E.: M7: an efficient size-resolved aerosol microphysics module for large-scale aerosol transport models, J. Geophys. Res., 109, 1-17, doi:10.1029/2003JD004485, 2004.

von Salzen, K.: Piecewise log-normal approximation of size distributions for aerosol modelling, Atmos. Chem. Phys., 6, 13511372, doi:10.5194/acp-6-1351-2006, 2006.

Wang, Q., Jacob, D. J., Spackman, J. R., Perring, A. E., Schwarz, J. P., Moteki, N., Marais, E. A., Ge, C., Wang, J., and Barrett, S. R. H.: Global budget and radiative forcing of black carbon aerosol: Constraints from pole-to-pole (HIPPO) observa- 
tions across the Pacific, J. Geophys. Res., 119, 2013JD020824, doi:10.1002/2013JD020824, 2014.

Wilcox, E. M.: Direct and semi-direct radiative forcing of smoke aerosols over clouds, Atmos. Chem. Phys., 12, 139-149, doi:10.5194/acp-12-139-2012, 2012.

Wilson, D. R. and Ballard, S. P.: A microphysically based precipitation scheme for the UK Meteorological Office Unified Model, Q. J. Roy. Meteor. Soc., 125, 1607-1636, doi:10.1002/qj.49712555707, 1999.

Wilson, D. R., Bushell, A. C., Kerr-Munslow, A. M., Price, J. D., Morcrette, C. J., and Bodas-Salcedo, A.: PC2: a prognostic cloud fraction and condensation scheme. II: Climate model simulations, Q. J. Roy. Meteor. Soc., 134, 2109-2125, doi:10.1002/qj.332, 2008.

Winker, D. M., Tackett, J. L., Getzewich, B. J., Liu, Z., Vaughan, M. A., and Rogers, R. R.: The global 3-D distribution of tropospheric aerosols as characterized by CALIOP, Atmos. Chem. Phys., 13, 3345-3361, doi:10.5194/acp-13-33452013, 2013.

Woodward, S.: Modeling the atmospheric life cycle and radiative impact of mineral dust in the Hadley Centre climate model, J. Geophys. Res., 106, 18155-18166, doi:10.1029/2000JD900795, 2001.
Yu, F. and Luo, G.: Simulation of particle size distribution with a global aerosol model: contribution of nucleation to aerosol and CCN number concentrations, Atmos. Chem. Phys., 9, 76917710, doi:10.5194/acp-9-7691-2009, 2009.

Yu, F., Luo, G., Bates, T. S., Anderson, B., Clarke, A., Kapustin, V., Yantosca, R. M., Wang, Y., and Wu, S.: Spatial distributions of particle number concentrations in the global troposphere: Simulations, observations, and implications for nucleation mechanisms, J. Geophys. Res., 115, D17205, doi:10.1029/2009JD013473, 2010.

Zarzycki, C. M. and Bond, T. C.: How much can the vertical distribution of black carbon affect its global direct radiative forcing?, Geophys. Res. Lett., 37, L20807, doi:10.1029/2010GL044555, 2010.

Zhang, K., O’Donnell, D., Kazil, J., Stier, P., Kinne, S., Lohmann, U., Ferrachat, S., Croft, B., Quaas, J., Wan, H., Rast, S., and Feichter, J.: The global aerosol-climate model ECHAM-HAM, version 2: sensitivity to improvements in process representations, Atmos. Chem. Phys., 12, 8911-8949, doi:10.5194/acp-12-8911-2012, 2012.

Zhang, L., Gong, S., Padro, J., and Barrie, L.: A size-segregated particle dry deposition scheme for an atmospheric aerosol module, Atmos. Environ., 35, 549-560, doi:10.1016/S13522310(00)00326-5, 2001. 